\title{
A bibliometric analysis of family firm internationalization research: Current themes, theoretical roots, and ways forward
}

\author{
Elena Casprini ${ }^{1 *}$, Marina Dabic ${ }^{2 a, 2 b}$, Josip Kotlar ${ }^{3}$, Tommaso Pucci ${ }^{4}$ \\ https://doi.org/10.1016/.i.ibusrev.2020.101715
}

\author{
${ }^{1}$ Department of Business and Law, University of Siena, Italy \\ ${ }^{2 a}$ Department of Management, Nottingham Business School, Nottingham, UK; ${ }^{2 b}$ Faculty of Economics and \\ Business, University of Zagreb, Croatia \\ ${ }^{3}$ School of Management, Politecnico di Milano, Italy \\ ${ }^{4}$ Department of Business and Law, University of Siena, Italy
}

Volume 29, Issue 5, October 2020, 101715

Cited as: Casprini, E., Dabic, M., Kotlar, J., \& Pucci, T. (2020). A bibliometric analysis of family firm internationalization research: Current themes, theoretical roots, and ways forward. International Business Review, 29(5):101715; https://doi.org/10.1016/j.ibusrev.2020.101715

This paper presents a bibliometric analysis and a systematic literature review of 161 core contributions concerning family firm internationalization. A bibliographic coupling analysis and a co-citation analysis reveal the richness of family firm internationalization research and help to organize this large body of work into five thematic clusters and seven theoretical roots. By examining the linkages between research themes and theoretical roots, we advance an integrative framework, clarifying the variety of research paths available regarding the internationalization of family firms, and identifying new and important research avenues for further developing the field.

Keywords: internationalization; family firms; bibliometric analysis; literature review.

\section{Introduction}

The importance of internationalization has grown considerably over the last few decades. Following changes in the global environment, including new forms of communication, new modes of transportation, and increased opportunities to manage international value chains (Zucchella, Palamara, \& Denicolai, 2007), academic literature on business internationalization has grown rapidly (Onetti, Zucchella, Jones, \& McDougall-Covin, 2012; Casillas \& Moreno-Menéndez, 2017; Paul, 
Parthasarathy, \& Gupta, 2017). More recently, internationalization has also attracted significant interest amongst family business scholars (Arregle, Duran, Hitt, \& van Essen, 2017; Kontinen \& Ojala, 2010a; Pukall \& Calabrò, 2014). However, compared to general management literature, research on family firm internationalization is yet to flourish.

The recent spike in interest regarding family firm internationalization, observed across multiple fields of literature, is motivated by the observation that internationalization may present family firms with unique opportunities and threats (Eberhard \& Craig, 2013; Zahra, 2003). New markets and clients could bring forward new benefits, notwithstanding the exploitation of the family brand at an international level, and potential synergy with other firms operating in foreign countries. However, going international can also expose family firms to competitive risks, uncertainty regarding different cultural and institutional contexts, as well as unique issues related to a family's desire to protect their “socioemotional wealth" (Gomez-Meja, Makri, \& Kintana, 2010). This ongoing research effort has shown that family involvement in firm ownership and management plays a significant role in relation to a variety of issues pertaining to internationalization strategy and operations. However, the heterogeneity of topics, theories, and empirical methods in this fast-growing stream of literature has also led to a highly fragmented set of theories and empirical evidence, which may ultimately constrain knowledge accumulation (e.g. Arregle et al., 2017). Previous research has sought to adopt different theoretical angles, such as the process model of internationalization, the network model of internationalization, the resource-based view, and Dunning's eclectic paradigm (cf. Kontinen \& Ojala, 2010a). Similarly, Graves \& Thomas (2004) observed different perspectives, including (i) an economic perspective, mainly focused on explaining foreign direct investment (FDI) by large firms; (ii) a process perspective, adopting stage models and focusing on the role of knowledge; (iii) a relational perspective, stressing the role of networks; and (iv) a capability perspective. Likewise, extant research has identified a broad array of business-, location-, network-, and entrepreneurspecific factors and drivers that may affect internationalization processes in family firms (Zucchella et al., 2007).

As is common in the early stages of a new research field as it expands and develops towards maturity (Gedajlovic, Carney, Chrisman \& Kellermanns, 2012), research that endeavours to take stock and organize the growing amount of literature on family firm internationalization is critical in order to map, analyse, and integrate existing knowledge on the topic. This goal was pursued by Pukall and Calabrò (2014), who presented a qualitative review of 72 journal articles published from 1980 to 2012 in an attempt to resolve mixed findings in the field's early literature and develop a revised Uppsala Model to explain the role of risk attitudes, knowledge, and networks in explaining internationalization processes in family firms. More recently, Casillas and Moreno-Menéndez (2017) 
examined 102 papers from 1991 to 2015 to broaden the previous work beyond the innovation process and incorporate other areas of research, such as the organizational behaviour of multinational companies and cross-cultural management, among others. As a result, the authors identified six promising areas for research at the intersection between family business and international business literature. Arregle et al. (2017) presented a meta-analysis of 76 studies across 41 countries in order to estimate the effects of family control on the scale and scope of internationalization, along with the moderating effects of institutions, such as shareholder protection and trust.

Previous reviewing efforts have been highly instrumental to advancing our cumulative knowledge on family firm internationalization. However, qualitative reviews have inherent limitations. For example, single-expert reviews help to assess the state of a field and launch discussions on its future development. However, these reviews generally tend to suffer from problems of subjectivity and possible biases. Moreover, the information-processing capacity of individual researchers is constrained in assessing publications that proliferate at high rates, such as in the field of family firm internationalization. Consequently, qualitative reviews are limited when it comes to dealing with the variety of views on how family firm internationalization is to be understood and studied. As the amount of scholarly literature quickly grows, it is important to continuously update our existing knowledge in order to identify new and more pressing questions as well as emerging research directions. In view of these limitations, a structured quantitative approach to existing literature can assist in exploring the scope of family firm internationalization research in the broader field of management, detecting current research schools and perspectives within the field, and pushing the envelope by identifying hitherto unaddressed issues and disconnected subfields. Accomplishing these goals will substantiate and complement qualitative literature reviews of family firm internationalization research and help to cross-validate their findings and assessments. Research in other fields indicates that such computational methods are optimal in reviewing and encapsulating a cutting-edge and dynamic field (Iwami et al., 2020). Additionally, bibliometric and scientometric citation methods are particularly valuable when addressing a vast research field scattered across many academic domains (Kajikawa et al., 2007; Boyack \& Klavans, 2010; Dabić, Maley, Dana, Novak, Pellegrini, \& Caputo, 2019; Habib \& Afzal, 2019; Rialp, Merigó, Cancino, \& Urbano, 2019). To provide an alternative to qualitative reviews, we employ bibliometric methods, which have the potential to complement existing review efforts and advance knowledge in the field by systematically identifying the most active and influential articles and journals in the field, revealing collaboration networks and clusters of contributions to existing literature. Specifically, we use two different citation analysis methods - bibliographic coupling and co-citation - combined with the in-depth reading and 
reviewing of 161 selected papers, published between 1991 and 2019, to provide an updated systematic overview of existing family firm internationalization research.

Our analysis outlines the temporal trends in publications on the topic, highlighting a considerable rise in publications in the last decade, and identifying the main journals in which research on family firm internationalization has been published over time. This analysis attests to the emancipation of family firm internationalization as a distinct and yet highly heterogeneous field of research. Using bibliographic coupling analysis, we examine shared references amongst published articles and identify five thematic clusters that describe the 'intellectual core' of existing family firm internationalization research, thus capturing major ongoing research themes: (1) ownership, (2) diversification decisions, (3) networks, (4) international entrepreneurial orientation, and (5) residual contributions. The co-citation analysis of the literature adds a complementary perspective which clarifies the intellectual foundations of existing research and the corresponding theoretical lenses used in existing studies. The co-citation analysis revealed seven clusters defined by coherent sets of theoretical perspectives: (1) the Resource-Based View and the Uppsala Model; (2) Agency Theory and Dunning's Eclectic Paradigm; (3) the Behavioural Agency Model and Born-global model of internationalization; (4) Social Capital, along with the revised Uppsala Model and reformulated International Entrepreneurship; (5) Stewardship Theory and International Entrepreneurship; (6) Family Firms' Idiosyncrasies; and (7) Emerging Markets. For each cluster, we identified seminal papers constituting the foundations of the intellectual core of family firm internationalization research. Finally, we combined the results of the bibliometric coupling and co-citation analyses in order to map the links between the multiple thematic clusters and theoretical foundations identified, thereby advancing an integrative model of family firm internationalization research to take stock and make sense of a heterogeneous field of research spanning multiple themes and theoretical perspectives. In doing so, we identified recurrent research paths that have been explored in existing literature, as well as research paths that have not been explored as much and thus represent fruitful directions in which to advance the theoretical understanding of family firm internationalization. In the light of the above, we go on to discuss possible directions for further research.

The paper is structured as follows. After a detailed description of the state of the art (Section 2) and the methodology used (Section 3), based on a bibliographic coupling and a systematic literature review on the intellectual core of the internationalization of family firms, five thematic clusters are identified (Section 4.1). Then, based on the co-citation of the cited references, seven antecedents of the internationalization of family firms are identified and described (Section 4.2). The links between thematic clusters and theoretical roots are then presented (Section 4.3). Following this, an integrative 
model for analysing the internationalization of family firms is outlined (Section 4.4). Finally, conclusions, limitations, and suggestions for future research are provided (Section 5).

\section{State of the art: Existing conceptual backgrounds}

Literature on internationalization is wide and encompasses multiple disciplines. As such, multiple definitions of internationalization exist. Internationalization can be viewed in terms of scale (or depth), distinguishing between (i) exporting, done directly or indirectly (via intermediaries) by the firm; and (ii) foreign direct investment (FDI) or equity based foreign market entry (Surdu \& Mellahi, 2016), such as mergers and acquisitions (M\&A), greenfield investment, and brownfield investments (Meyer \& Estrin, 2001), but also horizonal and vertical FDI (Beugeldsdijk, Smeets, \& Zwinkels 2008). Additionally, internationalization can be seen in terms of its geographical scope (or breadth), i.e. in which countries the firm internationalizes (Laufs \& Schwens, 2014; Arregle et al., 2017). Measuring internationalization is therefore not an easy task and scholars are increasingly using composite measures in their quantitative studies. For the purpose of this paper, we adopt a broad definition of internationalization, which includes both the scale and scope of internationalization.

To date, five literature reviews on family firm internationalization have been published. Chronologically, the first was the work of Kontinen \& Ojala (2010a), who identified four theoretical frameworks linked to internationalization theory: the Uppsala Model; the Network Model (or Uppsala Model revised); the Resource-Based View Model; and Dunning's Eclectic Paradigm, each of which evidenced a specific aspect of internationalization. A second literature review was conducted by Pukall \& Calabrò (2014), who extended Kontinen \& Ojala's (2010a) contribution, proposing an integrated model of family firms' internationalization using the Socioemotional Wealth perspective and the revised Uppsala Model. The third literature review was developed by Marìn-Anglada, CampaPlanas, \& Hernàndez-Lara (2014), who proposed agency and stewardship theories as main theoretical lenses through which the internationalization of family firms could be explained. The fourth literature review was the meta-analysis, performed by Arregle et al. (2017), which took stock of existing empirical results concerning the relationships between family control and internationalization. This analysis showed that family firms did not differ significantly from non-family firms in terms of internationalization scale, but they did display a lower geographical scope of internationalization. Finally, Casillas \& Moreno-Menendez (2017) looked at the intersection between family business and international business literature, providing an interesting framework that highlighted six major gaps at the intersection of the two fields. Table 1 summarizes these review papers, their review methods, and their key contributions. 


\begin{tabular}{|c|c|c|c|}
\hline Author (Year) & Source Title & Type of Review & Key contributions \\
\hline 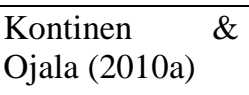 & $\begin{array}{l}\text { Journal of Family } \\
\text { Business Strategy }\end{array}$ & $\begin{array}{l}\text { Qualitative } \quad \text { literature } \\
\text { review on } 25 \text { contributions }\end{array}$ & $\begin{array}{l}\text { Summarizes main theories as applied to } \\
\text { family firm internationalization. }\end{array}$ \\
\hline $\begin{array}{l}\text { Marìn-Anglada, } \\
\text { Campas-Planas, } \\
\& \quad \text { Hernandez- } \\
\text { Lara }(2014)\end{array}$ & Intangible Capital & $\begin{array}{l}\text { Qualitative literature } \\
\text { review on } 92 \text { contributions }\end{array}$ & $\begin{array}{l}\text { Focuses and contrasts two specific theories as } \\
\text { applied to family firm internationalization } \\
\text { (agency and stewardship theory). }\end{array}$ \\
\hline $\begin{array}{l}\text { Pukall \& } \\
\text { Calabrò (2014) }\end{array}$ & $\begin{array}{l}\text { Family Business } \\
\text { Review }\end{array}$ & $\begin{array}{l}\text { Qualitative } \quad \text { literature } \\
\text { review on } 72 \text { contributions }\end{array}$ & $\begin{array}{l}\text { Links theories and family firm heterogeneity } \\
\text { and develops an integrative model which } \\
\text { updates/adapts the Uppsala Model. }\end{array}$ \\
\hline $\begin{array}{l}\text { Arregle, Duran, } \\
\text { Hitt, \& van } \\
\text { Essen }(2017)\end{array}$ & $\begin{array}{l}\text { Entrepreneurship: } \\
\text { Theory and Practice }\end{array}$ & $\begin{array}{l}\text { Meta-analysis } \\
\text { contributions }\end{array}$ & $\begin{array}{l}\text { Focuses on the relationship between family } \\
\text { control and internationalization and uses } \\
\text { meta-analytical methods to test the overall } \\
\text { effects, as well as the role of institutional } \\
\text { context. }\end{array}$ \\
\hline $\begin{array}{l}\text { Casillas } \\
\text { Moreno- } \\
\text { Menendez } \\
(2017)\end{array}$ & $\begin{array}{l}\text { European Journal } \\
\text { of Family Business }\end{array}$ & $\begin{array}{l}\text { Qualitative literature } \\
\text { review on } 102 \text { papers }\end{array}$ & $\begin{array}{l}\text { Identifies } 6 \text { gaps based on the national } \\
\text { culture, the corporate governance, the risk } \\
\text { attitude, the objectives, the networks, and the } \\
\text { timing of internationalization. }\end{array}$ \\
\hline
\end{tabular}

Table 1. Overview of the literature reviews on internationalization and family firms (source: authors)

Although the five literature reviews summarized above are recent and provide several valuable contributions, they all fall short in unveiling, in a systematic way, the research topics addressed in this literature, along with their respective theoretical underpinnings. In other words, while each literature review provides a model or set of relationships developed according to one or more theoretical perspectives, qualitative review methods have inherent limitations that constrain the researcher's ability to capture the richness of a fast-growing and heterogeneous field of research. As suggested by Vogel \& Güttel (2013), in order to sustain the development of a research field, it is important to identify and disentangle the variety of intellectual traditions that exist within it and trace the evolution of the field over time. In other words, each literature review advances internationalization in family firms partially and in different ways. In contrast, the aim of this paper is fourfold:

1. To leverage bibliometric methods to systematically identify the variety of research themes studied in relation to family firm internationalization.

2. To leverage bibliometric methods to discern the diverse theoretical roots that influence literature pertaining to the internationalization of family firms.

3. To map the links between existing research themes and their respective theoretical roots.

4. To develop an integrative, multi-theoretical framework which identifies uncharted paths in family firm internationalization research and highlights important avenues for future research. 


\section{Methodology}

Literature review papers are particularly challenging as they can have different purposes and thus require different processes and structures (Palmatier, Houston, \& Hulland, 2018). Nonetheless, scholars clearly emphasize the need to ensure replicability for future research, thus asking colleagues to be as precise as possible in describing the steps followed. Many examples can be cited, such as data collection, data cleaning, and data analysis (Linnenluecke, 2017), when planning the review, data collection, information construction, and codebook building (e.g. López-Duarte, GonzálezLoureiro, Vidal-Suárez, \& González-Díaz, 2016). Consequently, we will describe the procedure followed, ensuring the reliability of the outcomes. In order to develop a conceptual framework that extends previous research and presents future research directions, the methodology of this paper is developed in five stages. We adapted the methodology performed by other scholars who used bibliometric techniques (e.g. Appio, Martini, Massa, \& Testa 2017; Elango, 2019; Linnenluecke, 2017). Firstly, we selected the intellectual core of papers on the internationalization of family firms. Secondly, we performed a bibliographic coupling analysis and a follow-up analysis of the content of the intellectual core, in order to identify the main themes. Thirdly, we identified theoretical roots using the co-citation analysis of the cited references. We then linked the themes of the intellectual core to their theoretical roots. Finally, an interpretive framework was created. It is interesting to note that several bibliometric techniques were used and that an increasing number of different types of software could be applied. For example, HistsCite ${ }^{\mathrm{TM}}$ provides a map of citations (for an application, see Linnenluecke, 2017). As a result of the scope of this paper, we focused on the bibliographic coupling and co-citation analysis of the documents (e.g. Appio et al., 2017; Elango, 2019) and we used VOSviewer 1.6.11 (Van Eck \& Waltman, 2010) as our software.

\subsection{Data collection, intellectual core identification, and intellectual core data cleaning}

\section{Data collection.}

Data collection was comprised of multiple sub-steps, namely identification of the keywords, selection of the database, and a search of the query in the selected database. We began by determining the keywords (keywords identification) to be considered, seeking to identify the intellectual core of the internationalization of family firms. As scholars refer to internationalization and family firms using different terms, all authors discussed which terms should be included in the search. This was a crucial step, as the inclusion or exclusion of a single keyword could lead to a broader or narrower initial set of contributions. Indeed, we considered 'family firm' and its synonyms, such as 'family business', as 
well as 'internationalization', but additionally considered related concepts, such as geographical diversification.

We then decided where to search (database selection). Several databases exist, such as Google Scholar, ISI Web of Science, Scopus, and other databases that are more subject specific (e.g. PubMed for medical publications). VOSviewer 1.6.11 supports several file types, either bibliographic database files (namely Web of Science, Scopus, Dimensions, and PubMed), reference manager files (namely RIS, EndNote, and RefWorks), or downloaded data throughout API (e.g. Wikidata, among others). Consequently, the technical features of the software led us to select only one of the aforementioned options. We chose Scopus database as it comprised a broader range of journals than ISI Web of Science. PubMed and Dimensions were not viable options when attempting to focus on specific fields of research.

Similar to research carried out for literature reviews (see, for example, Linnenluecke, 2017), publications were identified throughout a Boolean search by running a query (Search Query) for the following keywords in the Title, Abstract, or Keywords. We simultaneously searched for ("family firm*" OR "family business*" OR "family enterprise*” OR "family owned") AND ("internat*” OR "export*" OR "geographic* diversification*"). The asterisk (*) was included as this meant that the search included variations. We limited our search to articles and reviews, thus excluding conference proceedings and books, which were not considered 'certified knowledge' (Ramos-Rodríguez \& RuízNavarro, 2004). We selected only the contributions in English. We did not restrict the timeframe, thus considering forthcoming publications as well (cut-off: July 2019). We did not restrict the subject area, and a total of 510 contributions were identified.

\section{Intellectual core identification.}

In order to initially refine the database, we excluded 19 contributions that did not present an author's name and we then analysed the remaining 491 contributions. Two researchers independently reviewed the papers. When determining the inclusion criteria, the authors selected papers which specifically focused on internationalization (i.e. we therefore excluded publications in which the term internation* referred, for example, only to the sample considered or papers that focused on international training). Opinions were divided with regard to 34 papers, and these were finally excluded. A further refinement was performed in the third round, which excluded 24 more contributions. In total, 161 papers were identified as having an intellectual core focused on the internationalization of family firms. This result is particularly surprising considering the drastically smaller number of papers analysed in previous literature reviews (Arregle et al., 2017; Kontinen \& Ojala, 2010a; Pukall \& Calabrò, 2014), as it demonstrates a boom in the internationalization of family 
firm literature. The 161 publications selected do not comprise the five literature reviews that were excluded from the intellectual core. ${ }^{1}$

\section{Intellectual core data cleaning.}

Cleaning the database comprised of the intellectual core of 161 publications required several weeks due to the lack of a shared format in the papers' references. Most of the papers, in fact, did not use the same journal source for the same paper. These inconsistencies were particularly problematic as they could potentially have rendered it impossible to identify connections between publications, as evidenced by previous studies (e.g. Linnenluecke, 2017). For example, abbreviated journal sources such as "acad manag jour" or "acad. man. jour." were used in place of "academy of management journal". The same problem occurred with regards to the issues of the journal: within cited references, some journals had an issue number, whereas others did not. In addition to this, the same paper or book appeared written in different ways (up to over 50 times) in the cited references. Because of this, the authors had to manually clean the database in order to obtain consistency in their source formats.

The analysis of the 161 core publications revealed that there has been an increasing interest in the topic of internationalization in family firms, especially during the last decade (Figure 1). Additionally, we performed a search based on the keywords used by the articles' authors and looked at their evolution over time (see Appendix I).

Figure 1. Number of papers per year $(n=161)$ (source: authors)

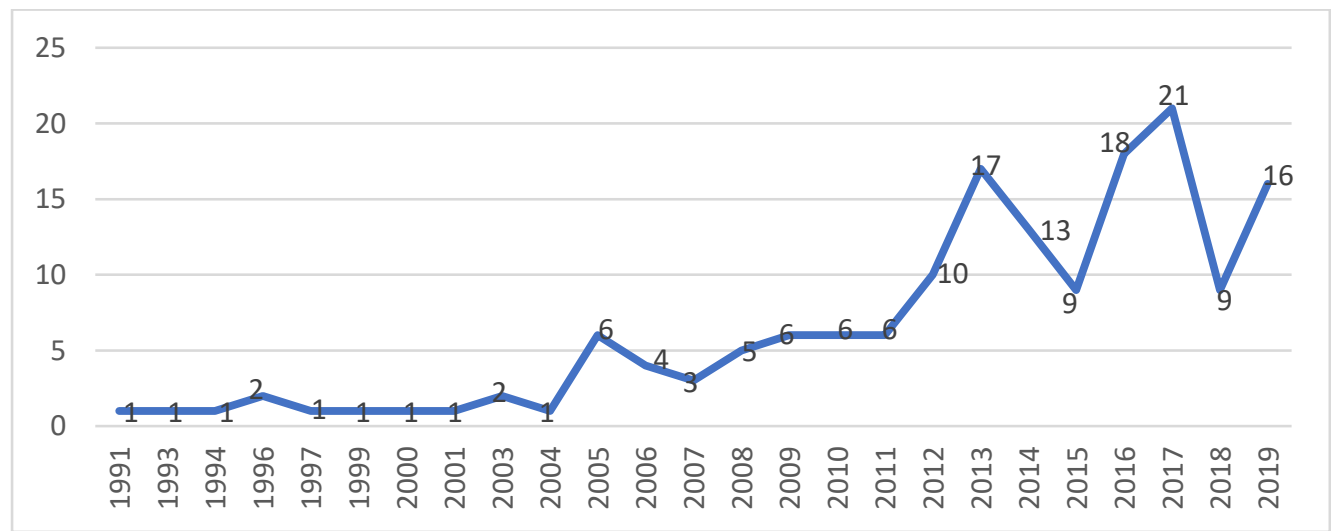

Table 2 shows the distribution of the intellectual core in the top ten journal sources. As shown in the table, most of the contributions are from the Family Business Review, the International Journal of Globalization and Small Business, and the International Business Review. It is worth mentioning that most of the publications are from journals belonging to the field of International Business Studies

\footnotetext{
${ }^{1}$ It is also worth noting that Casillas \& Moreno-Menendez (2017) does not belong to the SCOPUS database.
} 
(International Journal of Globalization and Small Business, International Business Review, Journal of International Business Studies, Global Strategy Journal, and Journal of World Business).

\begin{tabular}{lr}
\hline Journal & $\begin{array}{c}\text { Number of } \\
\text { Contributions }\end{array}$ \\
\hline Family Business Review & 13 \\
International Journal of Globalisation and Small Business & 11 \\
International Business Review & 8 \\
Business History & 7 \\
Journal of International Business Studies & 7 \\
Global Strategy Journal & 7 \\
Journal of Business Research & 7 \\
Journal of World Business & 6 \\
Journal of Small Business Management & 6 \\
Journal of Small Business and Enterprise Development & 6 \\
\hline
\end{tabular}

Table 2. Top 10 Journals

\subsection{Bibliographic coupling analysis}

We performed the bibliographic coupling analysis using VOSViewer 1.6.11 (Van Eck \& Waltman 2010). The aim of the bibliographic coupling was to group papers based on their shared references. The higher the reference overlap between the two papers, the more these two papers were deemed to belong to the same community. Considering the 161 papers constituting our intellectual core, the software returned five clusters that were manually analysed (after having analysed alternative scenarios by changing the value of the resolution parameter, we adopted a resolution value of 1 , with a minimum cluster size of 1 and maintained the default values of random start at 10, iterations equal to 10 , and random seed at 0 ). We examined each cluster, identifying the key research question for each paper, the main theoretical perspective adopted, the methodology used, and the key findings. In addition to this, we looked at the definition of 'family firm' adopted by each paper and we distinguished this from their internationalization scope and scale. The results of the bibliographic coupling did not depend on the point of time at which the analysis was conducted, as this was a static approach. Two documents were coupled if they had at least one reference in common. Bibliographic coupling is "suitable for detecting current trends and future priorities" (Vogel \& Güttel, 2013: 429).

\subsection{Co-citation analysis of the cited references}

We used the co-citation technique, as performed by VOSviewer 1.6.11 (Van Eck \& Waltman, 2010). The aim of the co-citation was to identify clusters of papers that shared similar content (Appio et al., 2017; Elango, 2019). Co-citation refers to the frequency with which two documents are cited together (i.e. they are included in the same reference list). This is a dynamic approach (Vogel \& Güttel, 2013), 
and the co-citation analysis was performed on the cited references of our intellectual core, of which there were 161 contributions. Out of 7,703 cited references, using three as the minimum number for a cited reference, 727 co-cited papers were identified, and these were allocated to six different clusters. For each of these co-cited papers, all of the abstracts and keywords were collected in order to identify each cluster's main topic. Co-citation looks at the theoretical roots of the intellectual core, grouping papers that share similar content. We manually analysed the cited references within each cluster in order to understand the sub-topics. While the text mining feature of VOSViewer 1.6.11 or other software such as NVivo could have been used, we elected to do this manually so as to better depict the nuances within each cluster.

\subsection{Linking the themes to their theoretical roots}

The third step of our analysis consisted of linking the themes that had emerged from the bibliographic coupling to their corresponding theoretical roots, which had emerged from the co-citation analysis. In doing so, we identified that the cited references within each single cluster came from the bibliographic coupling. Then, we compared these references with the cited references of the cocitation analysis and created a $5 * 7$ matrix (Appendix II) to understand to what extent each thematic cluster relied on the seven theoretical root clusters. Finally, we visualized the network using UCINET software (Borgatti, Everett, \& Freeman, 2002).

\subsection{Identifying an integrative framework}

The last step of our analysis consisted of developing an integrative framework. In order to develop this, we relied on the literature reviewed and highlighted the themes that had been addressed in previous research and the themes that needed further exploration.

\section{Where are we? Mapping what we know about family firm internationalization}

\subsection{Bibliographic coupling of the intellectual core}

Through the bibliographic coupling analysis, we identified five main clusters (Figure 2). These clusters represented the major research themes of family firm internationalization. As summarized in Table 3, each research theme had been specifically investigated in key journals. We looked at the main internationalization model adopted within each cluster (i.e. Uppsala, Dunning's eclectic paradigm, international entrepreneurship, Uppsala revised) and the main theoretical lens used. 


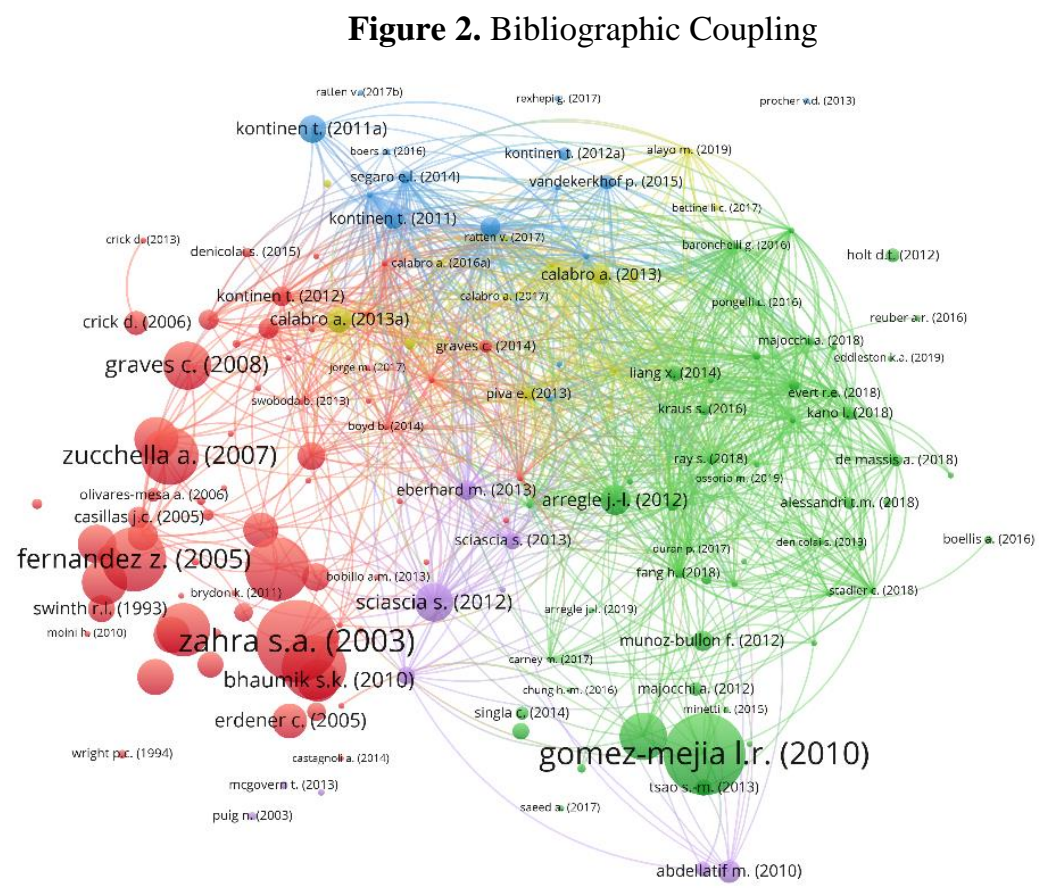

The first cluster (Red) was comprised of 66 contributions ranging from 1991 to 2019. The cluster brings together the seminal contributions on the internationalization of family firms and it is characterized by the leitmotif of OWNERSHIP. As such, it was named the OWNERSHIP cluster (Figure 3). Presenting mostly quantitative contributions, this cluster stresses the ways in which family firms - characterized by the fact that their ownership mainly belongs to a family - internationalize less than family firms (Fernandez \& Nieto, 2005, 2006; Zahra, 2003). This stream of research has often argued that family owners are risk averse, thus perceiving internationalization as dangerous. The deficit of internationalization is also due to the owner's individual characteristics, such as a lack of previous experience, age (Davis \& Harveston, 2000), or managerial capabilities. Therefore, it was not surprising to find contributions highlighting the fact that risk aversion can be mitigated when there are external shareholders (Cerrato \& Piva, 2012; Fernando \& Nieto, 2005). 
Figure 3. Bibliographic coupling: OWNERSHIP cluster (source: authors)

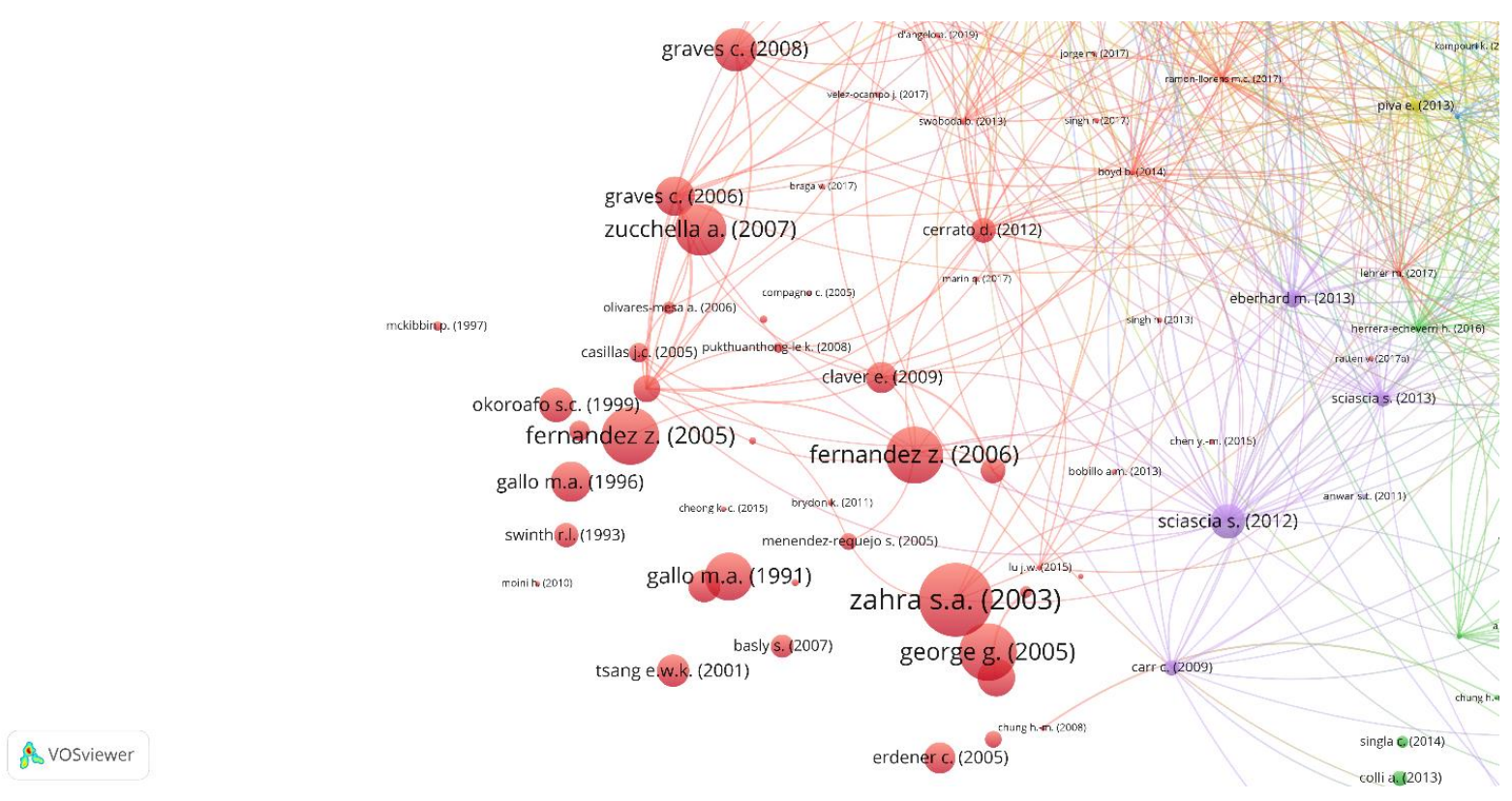

The second cluster (Green) consists of 51 contributions spanning from 2008 to 2019. It focuses on DIVERSIFICATION DECISIONS (Arregle, Naldi, Nordqvist, \& Hitt, 2012; Holt, 2012; Sirmon, Arregle, Hitt, \& Webb, 2008) (Figure 4). The top cited paper is by Gomez-Meja et al. (2010). Diversification decisions are determined based on the type of ownership structure. For example, Sanchez-Bueno \& Usero (2014) observe that the presence of financial shareholders correlates with international diversification. Additionally, the board of directors' characteristics, such as the level of family control (Arregle et al., 2012) and the board's gender diversity (Saeed, Yousaf, \& Alharbi, 2017), may boost internationalization. For example, international diversification is greater when the board of directors of a family-owned firm has a higher proportion of independent directors (Majocchi \& Strange, 2012) and when family managers have previous foreign work experience (Majocchi, D'Angelo, Forlani, \& Buck, 2018) - a characteristic that also influences their choice of entry mode (Boellis, Mariotti, Minichilli, \& Piscitello, 2016). Additionally, one group of papers looks at ownership heterogeneity. Pongelli, Caroli, \& Cucculelli (2016) focused on different levels of family ownership (founder, family members, or other families) and found that this influenced entry mode choices. Specifically, founder owned firms tended to choose equity rather than cooperation with third parties, thus opting for family control. An interesting study, provided by Kraus, Mensching, Calabrò, Cheng, \& Filser (2016), uses fuzzy-set qualitative comparative analysis in order to identify different levels of socioemotional wealth and ascertain their combination with external ownership as a means through which to reach internationalization. Focusing on family-managed SMEs, Hennarth, Majocchi, \& Forlani (2019) introduce the global niche business model, suggesting that, while family firms export less in comparison to non-family SMEs, this gap could be bridged by selling quality 
products in global niches. Moreover, family involvement in management, compared to ownership only, tends to favour internationalization (Alessandri, Cerrato, \& Eddleston, 2017).

This second cluster is also characterized by a growing number of recent papers considering the role of context (e.g. Arregle, Hitt, \& Mari, 2019) and focusing more on the bifurcation bias perspective (e.g. Verbeke, Yuan, \& Kano, 2019). For example, complementing the research of Hennarth et al. (2019), Eddleston, Sarathy, \& Banalieva (2019) show that the niche strategy has different effects on internationalization depending on whether family firms are from more or less developed markets and whether they have strong or weak professionalization practices.

However, there are contrasting results regarding product and international diversification strategies in family firms. On the one hand, there are scholars that suggest that family firms perform better than non-family firms when they engage jointly in product and international diversification (Muñoz-Bullón \& Sánchez-Bueno, 2012). On the other hand, there are authors (Delbufalo, Poggesi, \& Borra, 2016) who note that categorization as a family firm negatively influences the performance of companies that are both product and internationally diversified (Delbufalo et al., 2016).

Figure 4. Bibliographic coupling: DIVERSIFICATION DECISIONS cluster (source: authors)

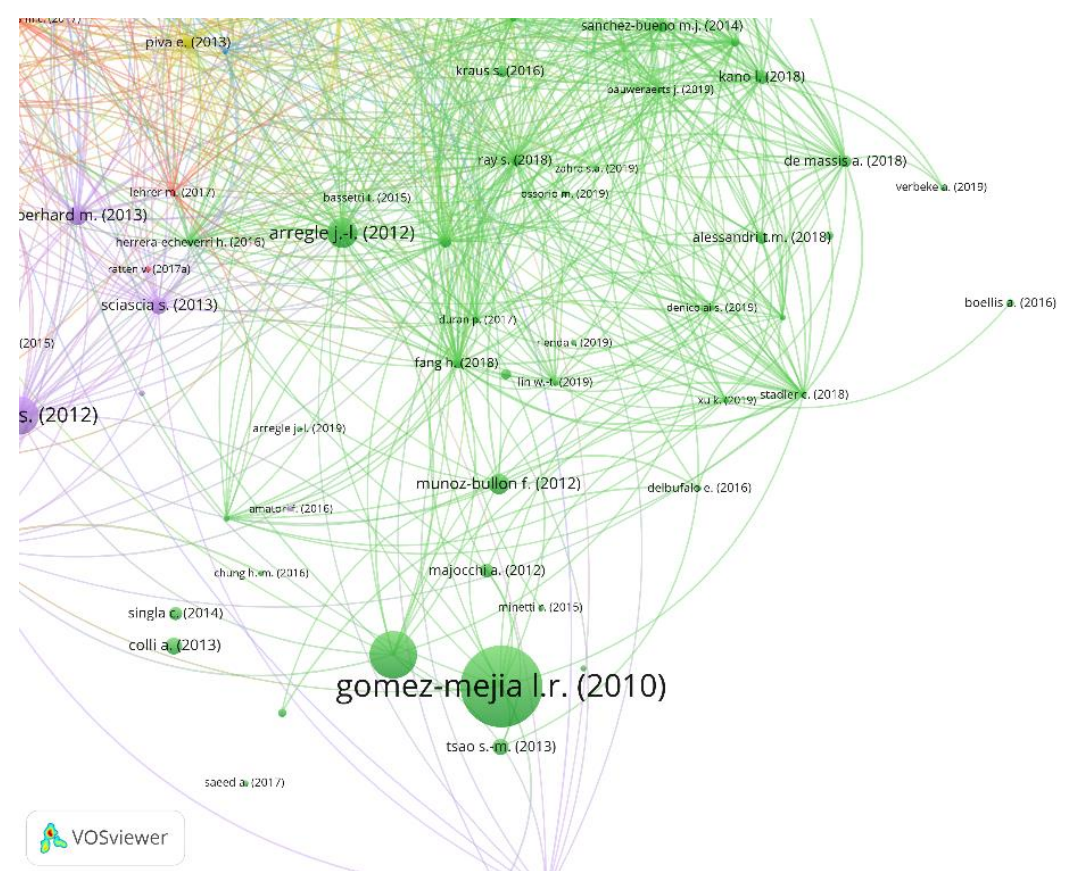

The third cluster (Blue) is comprised of 17 contributions spanning from 2011 to 2015. The leitmotif of the cluster concerns the role of NETWORKS in internationalization (Figure 5). This stream of research stresses the fact that not all networks are equal and that they may play different roles along the internationalization process. For example, in order to understand market opportunities, formal ties 
are more important than informal ties (Kontinen \& Ojala, 2011a). In addition to this, strong and formal ties are important in post-entry mode (Kontinen \& Ojala, 2011b). Some pieces of research, moving from stewardship theory, observe that the presence of a strategically flexible top management team, able to exploit its social capital, is related to higher internationalization (Segaro, Larimo, \& Jones, 2014).

Figure 5. Bibliographic coupling: NETWORKS cluster (source: authors)

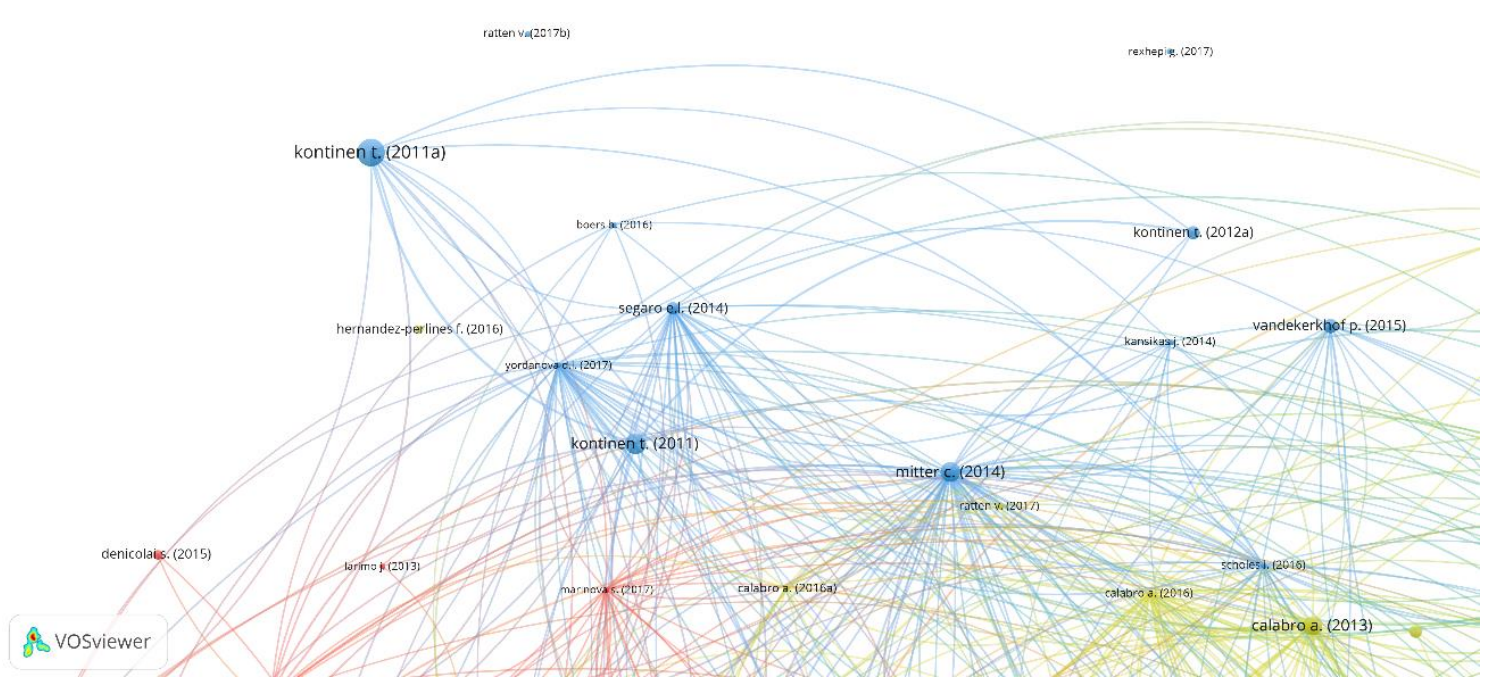

The fourth cluster (Yellow) consists of 13 contributions ranging from 2013 to 2019 and it refers to INTERNATIONAL ENTREPRENEURIAL ORIENTATION (IEO) (Figure 6). This cluster is comprised of the most recent contributions and, consequently, it also provides a higher degree of complexity in terms of the variables considered, with regard to both family firm heterogeneity and internationalization performance measurements. This cluster is grounded in international entrepreneurship literature, according to which companies discover and exploit opportunities across national borders (Oviatt \& McDougall, 2005). Indeed, this cluster sheds light on the factors that trigger international entrepreneurship, such as the upcoming generation's involvement (Calabrò, Brogi, \& Torchia, 2016a) and the role of entrepreneurs and top management teams (Calabrò \& Mussolino, 2013). The key focus here is to understand how family firms balance their international growth desire and their need to maintain family control. Some important factors are those of mutual trust (Calabrò et al., 2016a), competence-based and integrity-based trust (Calabrò \& Mussolino, 2013), and the presence of multiple generations (Calabrò, Torchia, Pukall, \& Mussolino, 2013). 
Figure 6. Bibliographic coupling: INTERNATIONAL ENTREPRENEURIAL ORIENTATION cluster (source: authors)

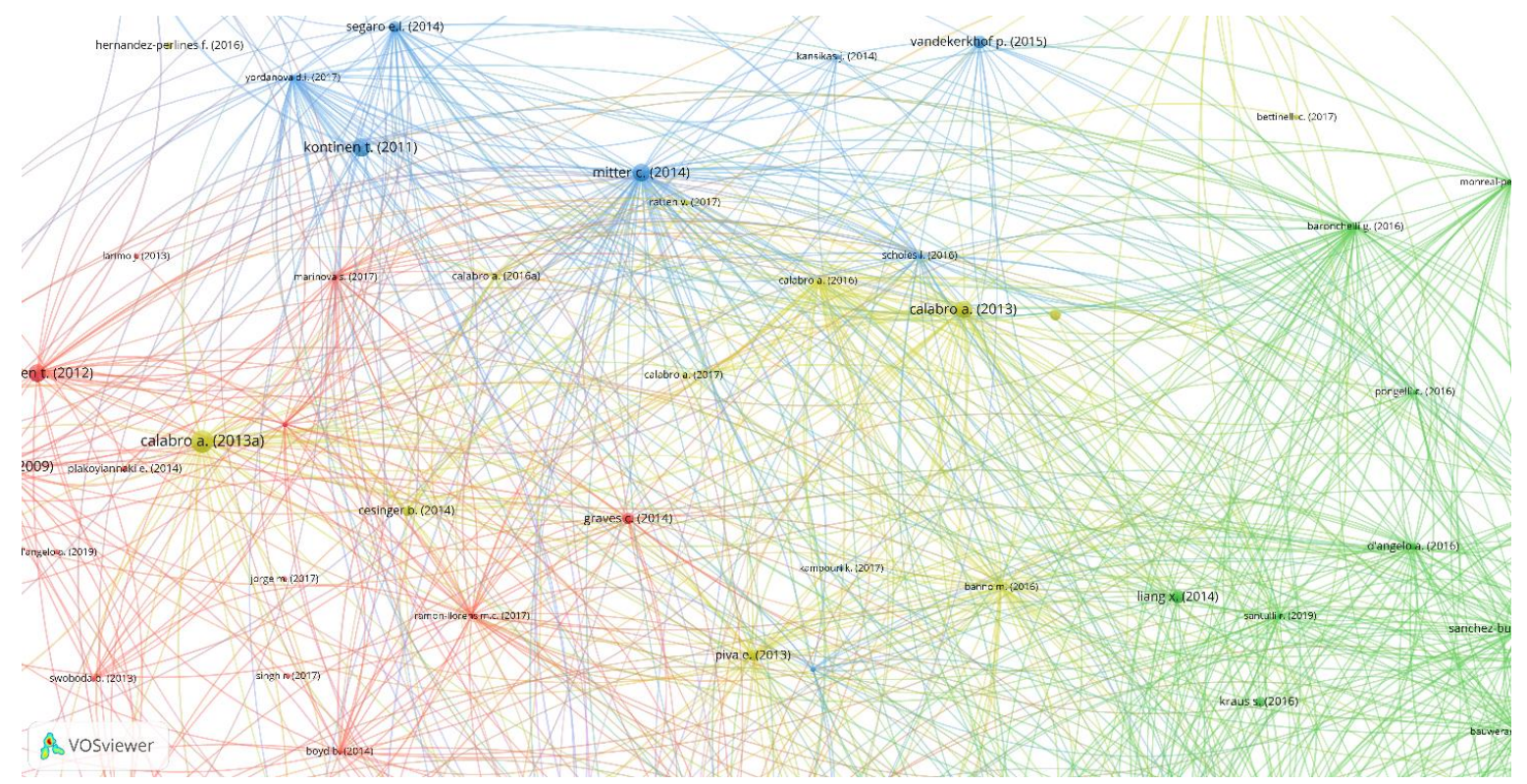

The fifth cluster (Purple) is comprised of 12 papers spanning from 1996 to 2016. The cluster consists of RESIDUAL CONTRIBUTIONS covering a variety of topics (Figure 7). The most cited paper is by Sciascia, Mazzola, Astrachan, \& Pieper (2012), which looks at the nonlinear relationships between ownership and internationalization. Other contributions are concerned with entry modes, such as joint ventures (Abdellatif, Amann, \& Jaussaud, 2010; Hamill \& Wersun, 1996; Kuo, Kao, Chang, \& Chiu, 2012), alliances or wholly owned subsidiaries, and those factors - such as international experience (Kuo et al., 2012) - that might influence the choosing of one specific entry mode over the others. Moreover, in this cluster, there are several papers covering internationalization histories at either national or company levels. 
Figure 7. Bibliographic coupling: RESIDUAL CONTRIBUTIONS cluster (source: authors)

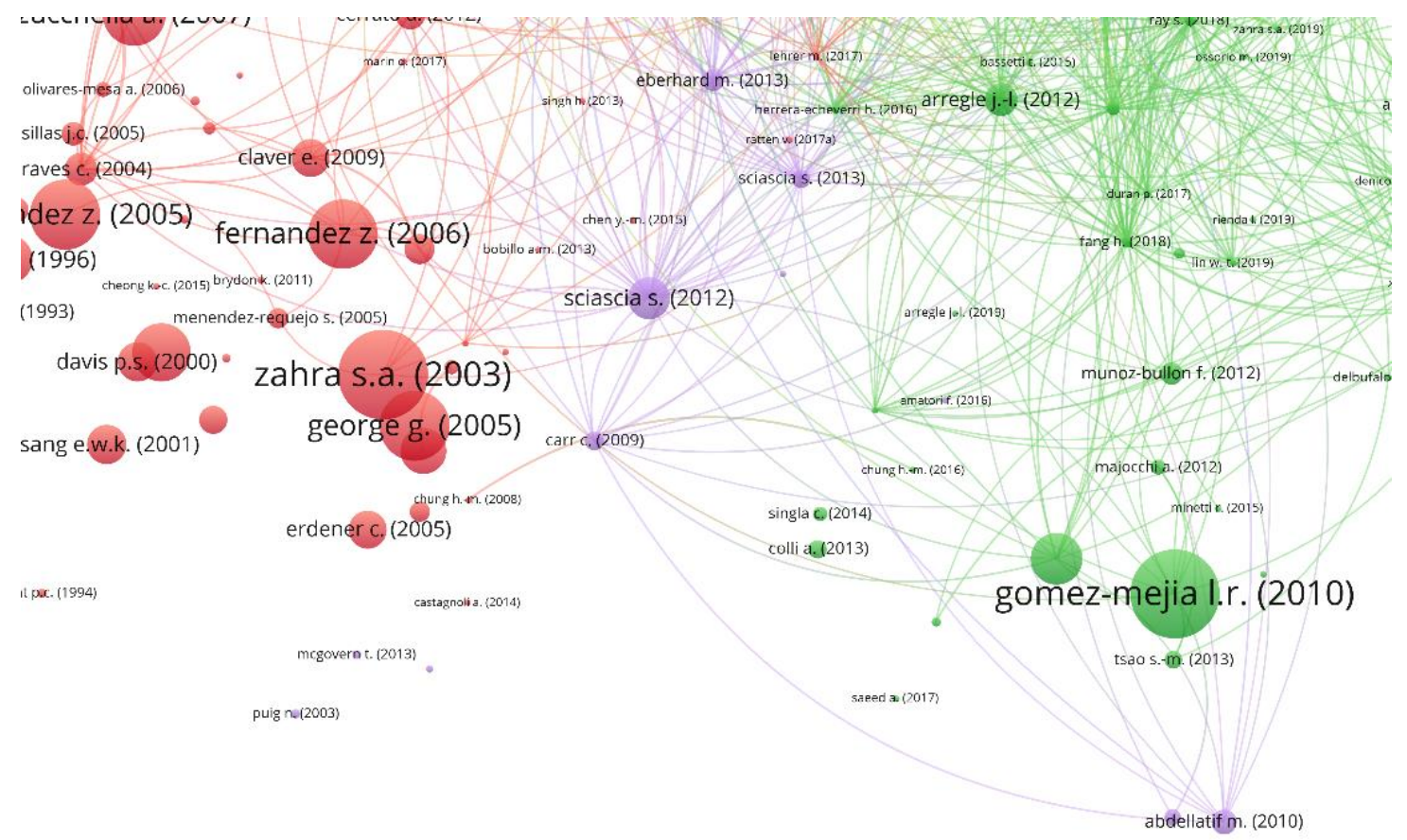

\begin{tabular}{|c|c|c|c|c|c|c|c|}
\hline Cluster & $\begin{array}{l}\text { Colour } \\
\text { on the } \\
\text { map }\end{array}$ & $\begin{array}{l}\text { Number } \\
\text { of } \\
\text { papers }\end{array}$ & $\begin{array}{l}\text { Range } \\
\text { of } \\
\text { links }\end{array}$ & $\begin{array}{l}\text { Time } \\
\text { span }\end{array}$ & Main sources & Top cited papers & Main topics \\
\hline 1 & Red & 66 & $9-152$ & $\begin{array}{l}1991- \\
2019\end{array}$ & $\begin{array}{l}\text { Family Business } \\
\text { Review (11), } \\
\text { International } \\
\text { Journal of } \\
\text { Globalization and } \\
\text { Small Business (9) }\end{array}$ & $\begin{array}{l}\text { Zahra (2003); Fernandez \& } \\
\text { Nieto (2005; 2006); } \\
\text { George, Wiklund, \& Zahra } \\
(2005)\end{array}$ & - Ownership \\
\hline 2 & Green & 51 & $\begin{array}{l}40- \\
151\end{array}$ & $\begin{array}{l}2008- \\
2019\end{array}$ & $\begin{array}{l}\text { Global Strategy } \\
\text { Journal } \\
\text { Journal } \\
\text { International } \\
\text { Business } \\
\text { (5) }\end{array}$ & $\begin{array}{l}\text { Gomez-Meja et al. (2010); } \\
\text { Sirmon et al. (2008); } \\
\text { Arregle et al. (2012) }\end{array}$ & $\begin{array}{l}\text { - Diversification } \\
\text { Decisions }\end{array}$ \\
\hline 3 & Blue & 17 & $6-149$ & $\begin{array}{l}2011- \\
2015\end{array}$ & $\begin{array}{l}\text { Journal of Small } \\
\text { Business } \\
\text { Management (3), } \\
\text { World Review of } \\
\text { Entrepreneurship, } \\
\text { Management and } \\
\text { Sustainable } \\
\text { Development (2), } \\
\text { Review } \\
\text { International of }\end{array}$ & $\begin{array}{l}\text { Kontinen \& Ojala (2011a); } \\
\text { Kontinen \& Ojala (2011b); } \\
\text { Mitter, Duller, Feldbauer- } \\
\text { Durstmuller, \& Kraus } \\
(2014)\end{array}$ & - Network \\
\hline
\end{tabular}




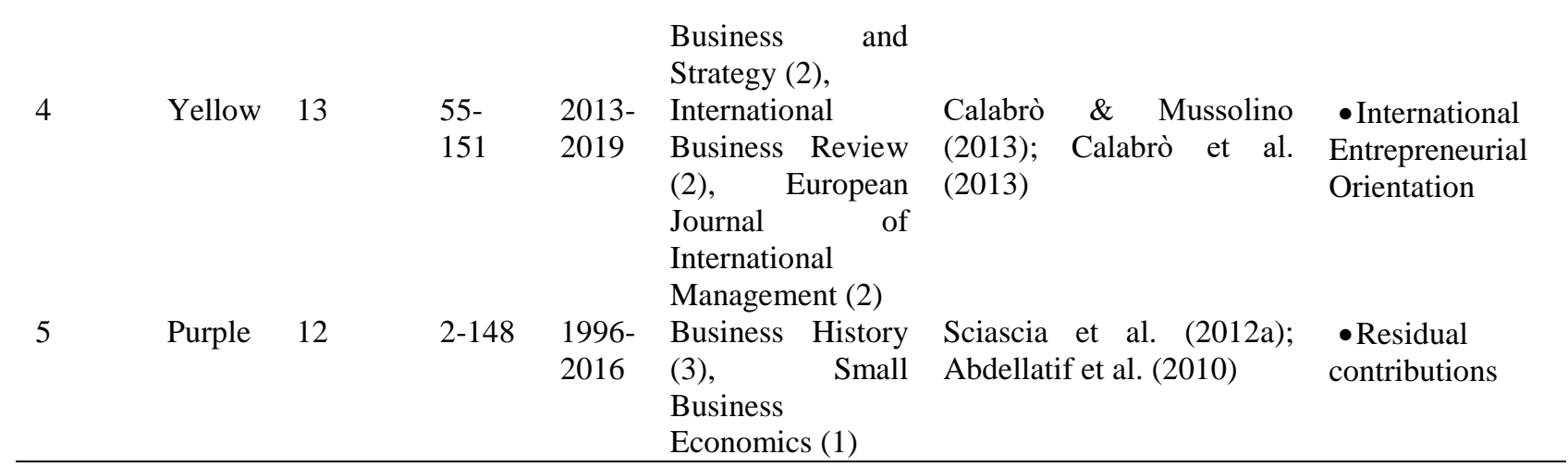

Table 3. Bibliographic coupling

\subsection{The theoretical foundations of family firm internationalization research}

The second step of our analysis focused on identifying the intellectual foundations of existing research on family firm internationalization; focusing specifically on the theoretical lenses used in existing studies. The co-citation analysis established seven clusters (Figure 8), all of which differ in terms of the theoretical lenses adopted. The analysis carried out reveals the theories and seminal papers constituting the foundations of the intellectual core.

Figure 8. Co-citation analysis $(n=161)$

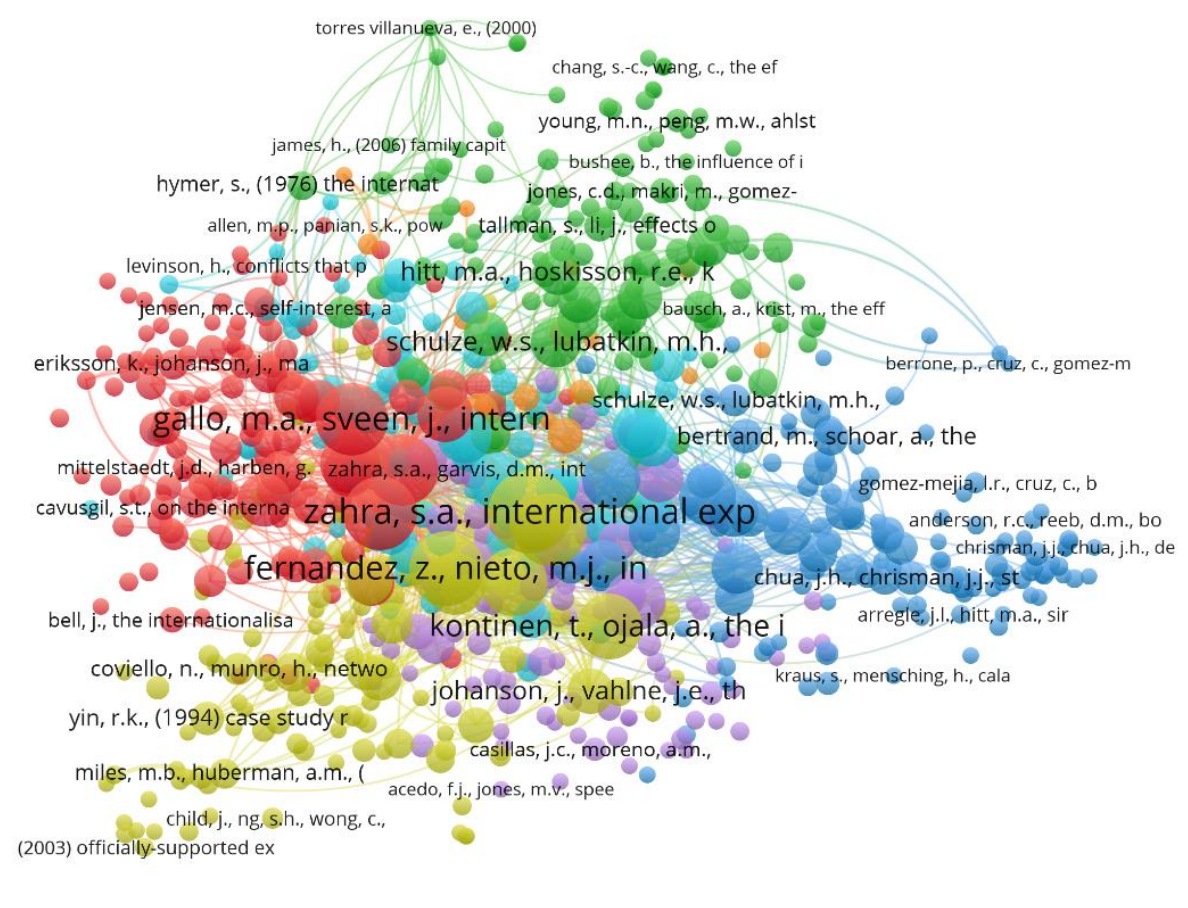


Cluster 1 (Red): This cluster is comprised of 133 contributions, spanning from 1959 to 2007. The main journals included are the Journal of International Business Studies (21), the Family Business Review (18) and the Journal of Small Business Management (8). The main contributions are Gallo \& Pont (1996), Gallo \& Sveen (1991) and Johanson \& Vahlne (1977). This cluster mainly relies on the RESOURCE-BASED VIEW and is characterized by the internationalization pioneers of the original UPPSALA MODEL (Johanson \& Vahlne, 1977) and the first contributions regarding the internationalization of family firms (Gallo \& Sveen, 1991; Gallo \& Pont, 1996). Moving on from the resource-based view, the original Uppsala Model focuses on the processes of knowledge development and resource commitment (Vahlne \& Johnson, 2017) and consists of the stage and change aspects of internationalization. It is therefore not surprising that this cluster mainly relies on the resource-based view (Barney, 1991; Penrose, 1959; Peteraf, 1993) and dynamic capabilities (Teece, Pisano, \& Shuen, 1997). The seminal paper on familiness by Habbershon and Williams (1999) is worth acknowledging as a key text explaining the unique resource of family businesses. In addition to this, the cluster also deals with personal factors: human capital (Manolova, Brush, Edelman, \& Greene, 2002) and human resources (Gomez-Meja, 1988).

Cluster 2 (Green): This cluster is comprised of 129 contributions ranging from 1966 to 2013. There are contributions from the Strategic Management Journal (15), the Journal of International Business Studies (13) and the Academy of Management Journal (11). The top cited papers are those by Schulze, Lubatkin, Dino, \& Buchholtz (2001) and Hitt, Hoskisson, \& Kim (1997). The cluster mainly relies on AGENCY THEORY as its main theoretical perspective as well as, more recently, the mixed gamble perspective (Alessandri et al., 2017). The core of the cluster is made up of papers seeking to identify the consequences of agency costs (and the lack of agency costs) on a firm's performance and those seeking to highlight the mechanisms that might mitigate firm governance, such as CEO compensation (Gomez-Meja, Kintana, \& Macri, 2003; Sanders \& Carpenter, 1998). Incentives in family firms are different from those in non-family firms (Gomez-Meja et al., 2003). Incentives are important as they impact several key processes, such as effective monitoring (Hillman \& Dalziel, 2003). Key unique family firm factors, such as altruism, may influence pay incentives (Schulze, Lubatkin, \& Dino, 2002; 2003). Through an international lens, in this cluster, we can observe the presence of DUNNING'S ECLECTIC PARADIGM (Dunning, 1981, 1988), according to which internationalization can be explained in terms of ownership, location, and internalization advantages.

Cluster 3 (Blue): This cluster is comprised of 127 contributions spanning from 1979 to 2018. The main journals are Entrepreneurship Theory \& Practice (21), the Family Business Review (13) and the Journal of International Business Studies (13). The most cited papers are those of Sirmon \& 
Hitt (2003), Gomez-Meja et al. (2010), and George, Wiklund, and Zahra (2005). Going deeper into the analysis reveals that this cluster appears to largely rely on the BEHAVIOURAL AGENCY MODEL, a combination of agency theory and prospect theory which outlines the ways in which family firms address concerns about socioemotional wealth in their decision-making (Berrone, Cruz, \& Gomez-Meija, 2012). Some core elements in this cluster are the impact of governance structures on the management of resources (Sirmon \& Hitt, 2003), diversification decisions (Gomez-Meja et al., 2010), and internationalization (George et al., 2005). From the field of internationalization research, this cluster collects contributions linked to the BORN-GLOBAL FIRMS (Knight \& Cavusgil, 2004).

Cluster 4 (Yellow): This cluster is comprised of 117 contributions spanning from 1973 to 2015 in Journal of International Business Studies (13), Entrepreneurship Theory and Practice (11), and Family Business Review (10). The top cited papers are those of Zahra (2003), Fernandez, \& Nieto (2005), and Fernandez and Nieto (2006). However, beyond these seminal papers, the core element characterizing the cluster is the role of SOCIAL CAPITAL (Adler \& Kwon, 2002; Burt, 1997, 2000; Coleman, 1988; Nahapiet \& Goshal, 1998) and, to a certain extent, networks (Granovetter, 1973). These contributions stress the ways in which social capital, in its structural, relational, and cognitive dimensions (Nahapiet \& Goshal, 1998), represents an important resource for a firm's competitive advantage in obtaining a working knowledge of foreign market opportunities (Ellis, 2000) and in entering new markets (Ojala, 2009). Moreover, we can distinguish between inter- and intraorganizational relationships (Yli-Renko, Autio, \& Tontti, 2002). Family firms are unique in their social capital as they possess both the firm's and the family's social capital (Arregle, Hitt, Sirmon, \& Very, 2007). The cluster also comprises two (out of four) pillars of internationalization studies, namely the REVISED UPPSALA MODEL (Johanson \& Vahlne, 2009), which advocates the network view of internationalization, and the REFORMULATED definition of INTERNATIONAL ENTREPRENEURSHIP (Oviatt \& McDougall, 2005), highlighting the role that networks play in international opportunities. Finally, it is interesting to note that the cluster lists all of the seminal papers and books on qualitative approaches (e.g. Eisenhardt, 1989; Miles \& Huberman, 1994; Yin, 1994).

Cluster 5 (Purple): This cluster is comprised of 109 publications spanning from 1972 to 2016, in the Family Business Review (17), Entrepreneurship: Theory \& Practice (12) and Small Business Economics (6). The top cited papers are Sciascia et al. (2012), Zahra (2005), and Zahra, Ireland, and Hitt (2000). The core theoretical perspective is that of STEWARDSHIP THEORY, according to which managers are motivated to act in the interests of their principals and, consequently, they adopt pro-organizational behaviour (Davis, Schoorman, \& Donaldson, 1997). Contributions belonging to 
this cluster are particularly focused on the role of the top management team (Carpenter \& Friedrickson, 2001). This cluster offers several contributions to entrepreneurial orientation (Lumpkin \& Dess, 1996), family firms (Casillas, Moreno, \& Barbero, 2010; Naldi, Nordqvist, Sjoberg, \& Wiklund, 2007), and INTERNATIONAL ENTREPRENEURIAL ORIENTATION (Covin \& Miller, 2014).

Cluster 6 (Light Blue): This cluster is comprised of 103 references ranging from 1980 to 2011, most of these are from the Family Business Review (21), Entrepreneurship Theory \& Practice (8) and the Academy of Management Review (7). The cluster relates to FAMILY FIRMS' IDIOSYNCRACIES, presenting several references linked to the uniqueness of family firms. Indeed, this cluster counts the contributions towards the definition of family firms (Astrachan, Klein, \& Smyrnios 2002; Chua, Chrisman, \& Sharma, 1999) and dynamics (Bammens, Voordeckers, \& Van Gils, 2008; Cabrera-Suarez, Saa-Perez, \& Garcia-Almeida, 2001; Miller, Steier, \& Le Breton-Miller, 2003). Through this theoretical lens, we can observe the stewardship theory (Davis et al., 1997) and socioemotional wealth (Gomez-Meja, Cruz, Berrone, \& De Castro, 2011).

Cluster 7 (Orange): This cluster is comprised of 19 contributions from between 1977 and 2006. It has no specific journal, as in the previous clusters, but it clearly presents a group of papers linked to the EMERGING MARKETS - mainly in China (Erdener \& Shapiro, 2005; Tsang, 2002). This is a residual cluster.

Table 4 presents a summary of the key characteristics of the clusters.

\begin{tabular}{|c|c|c|c|c|c|c|c|}
\hline $\begin{array}{l}\text { Cluste } \\
r\end{array}$ & $\begin{array}{l}\text { Colo } \\
\text { ur on } \\
\text { the } \\
\text { map }\end{array}$ & $\begin{array}{l}\text { Num } \\
\text { ber } \\
\text { of } \\
\text { pape } \\
\text { rs }\end{array}$ & $\begin{array}{l}\text { Rang } \\
\text { e of } \\
\text { co- } \\
\text { citati } \\
\text { on } \\
\text { links }\end{array}$ & $\begin{array}{l}\text { Time } \\
\text { span }\end{array}$ & Main sources & Top cited papers & $\begin{array}{l}\text { Main theoretical } \\
\text { perspectives }\end{array}$ \\
\hline 1 & Red & 133 & $\begin{array}{l}58- \\
653\end{array}$ & $\begin{array}{l}1959 \\
- \\
2007\end{array}$ & $\begin{array}{l}\text { Journal of International } \\
\text { Business Studies (21), } \\
\text { Family Business Review } \\
(18) \text { Journal of Small } \\
\text { Business Management (8) }\end{array}$ & $\begin{array}{l}\text { Gallo \& Pont (1996); } \\
\text { Gallo \& Sveen } \\
\text { (1991); Johanson \& } \\
\text { Vahlne (1977) }\end{array}$ & $\begin{array}{l}\text { Resource-based } \\
\text { view; Uppsala } \\
\text { Model }\end{array}$ \\
\hline 2 & $\begin{array}{l}\text { Gree } \\
\mathrm{n}\end{array}$ & 130 & $\begin{array}{l}15- \\
502\end{array}$ & $\begin{array}{l}1966 \\
- \\
2013\end{array}$ & $\begin{array}{l}\text { Strategic } \\
\text { Journal (15), Journal of } \\
\text { International Business } \\
\text { Studies (13), Academy of } \\
\text { Management Journal (11) }\end{array}$ & $\begin{array}{l}\text { Schulze, Lubatkin, } \\
\text { Dino, \& Buchholtz } \\
(2001) ; \text { Hitt et al. } \\
(1997)\end{array}$ & $\begin{array}{l}\text { Agency theory; } \\
\text { Dunning's } \\
\text { Eclectic Paradigm }\end{array}$ \\
\hline 3 & Blue & 127 & $\begin{array}{l}31- \\
611\end{array}$ & $\begin{array}{l}1979 \\
- \\
2018\end{array}$ & $\begin{array}{l}\text { Entrepreneurship Theory \& } \\
\text { Practice (21), Family } \\
\text { Business Review (13), } \\
\text { Journal of International } \\
\text { Business Studies (13) }\end{array}$ & $\begin{array}{l}\text { Sirmon \& Hitt } \\
\text { (2003); Gomez-Meja } \\
\text { et al. (2010); George } \\
\text { et al. (2005) }\end{array}$ & $\begin{array}{l}\text { Behavioural } \\
\text { Agency Model; } \\
\text { Born-global }\end{array}$ \\
\hline 4 & $\begin{array}{l}\text { Yello } \\
\mathrm{w}\end{array}$ & 116 & $\begin{array}{l}38- \\
702\end{array}$ & $\begin{array}{l}1973 \\
- \\
2015\end{array}$ & $\begin{array}{l}\text { Journal of International } \\
\text { Business Studies (13), } \\
\text { Entrepreneurship Theory \& }\end{array}$ & $\begin{array}{l}\text { Zahra (2003); } \\
\text { Fernandez \& Nieto } \\
(2005) ; \text { Fernandez \& } \\
\text { Nieto (2006) }\end{array}$ & $\begin{array}{l}\text { Social Capital; } \\
\text { Revised Uppsala } \\
\text { Model; } \\
\text { Reformulated }\end{array}$ \\
\hline
\end{tabular}




\begin{tabular}{|c|c|c|c|c|c|c|c|}
\hline & & & & & $\begin{array}{l}\text { Practice (11), Family } \\
\text { Business Review (10) }\end{array}$ & & $\begin{array}{l}\text { International } \\
\text { Entrepreneurship }\end{array}$ \\
\hline 5 & $\begin{array}{l}\text { Purpl } \\
\mathrm{e}\end{array}$ & 109 & $\begin{array}{l}78- \\
580\end{array}$ & $\begin{array}{l}1972 \\
- \\
2016\end{array}$ & $\begin{array}{l}\text { Family Business Review } \\
\text { (17), Entrepreneurship } \\
\text { Theory \& Practice (12) and } \\
\text { Small Business Economics } \\
\text { (6) }\end{array}$ & $\begin{array}{l}\text { Sciascia et al. (2012); } \\
\text { Zahra (2005); Zahra } \\
\text { et al. (2000) }\end{array}$ & $\begin{array}{l}\text { Stewardship } \\
\text { theory; } \\
\text { International } \\
\text { Entrepreneurship }\end{array}$ \\
\hline 6 & $\begin{array}{l}\text { Light } \\
\text { blue }\end{array}$ & 103 & $\begin{array}{l}47- \\
572\end{array}$ & $\begin{array}{l}1980 \\
- \\
2011\end{array}$ & $\begin{array}{l}\text { Family Business Review } \\
(21), \quad \text { Entrepreneurship } \\
\text { Theory \& Practice (8), } \\
\text { Academy of Management } \\
\text { Review (7) }\end{array}$ & $\begin{array}{l}\text { Chua et al. (1999); } \\
\text { Gomez-Mejia, } \\
\text { Haynes, Nunez- } \\
\text { Nickel, Jacobson, \& } \\
\text { Moyano-Fuentes } \\
\text { (2007); }\end{array}$ & $\begin{array}{l}\text { Family firms' } \\
\text { idiosyncrasies }\end{array}$ \\
\hline 7 & $\begin{array}{l}\text { Oran } \\
\text { ge }\end{array}$ & 19 & $\begin{array}{l}23- \\
327\end{array}$ & $\begin{array}{l}1977 \\
- \\
2006\end{array}$ & $\begin{array}{l}\text { Administrative } \\
\text { Quarter }\end{array}$ & Tsang (2002) & $\begin{array}{l}\text { Emerging } \\
\text { Markets }\end{array}$ \\
\hline
\end{tabular}

Table 4. Co-citation analysis

\subsection{Linking bibliographic coupling with co-citation analysis}

When analysing these research themes alongside the internationalization of family firms, we examined the relationship between the cited references within each bibliographic coupling cluster as well as those belonging to the co-citation clusters. The aim of this was to understand what the theoretical roots of each bibliographic coupling cluster were. We looked at stronger (bolder) and weaker (narrower) ties between the related co-citation clusters in order to distinguish between wellestablished research paths and potential avenues for future research (as proposed in Section 4.4). Figure 9 provides a representation of the relationships obtained throughout Netdraw (Borgatti, 2002).

Figure 9. Linkages between bibliographic coupling (red) and co-citation (blue) clusters 


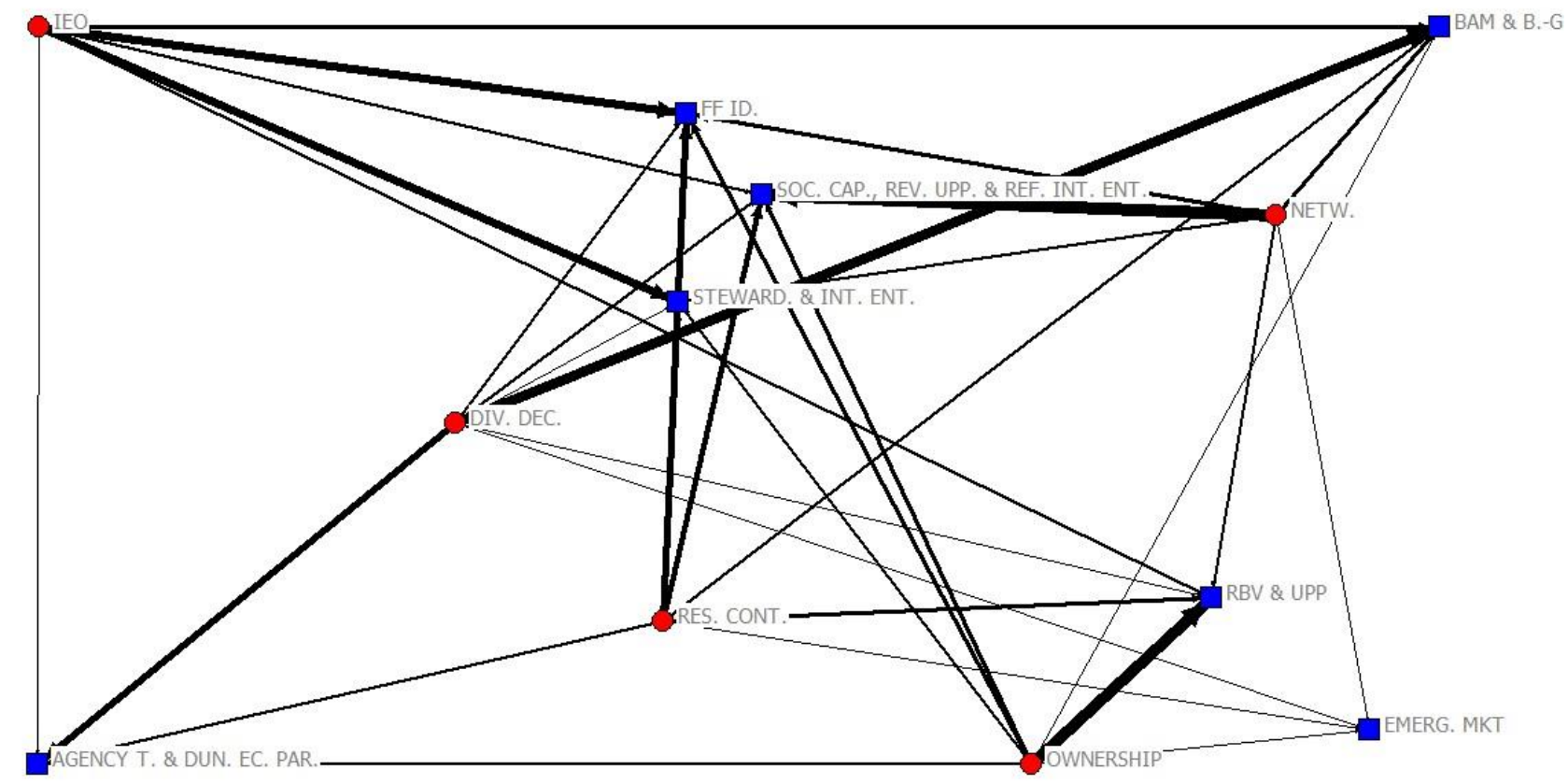

The thematic cluster of OWNERSHIP, as represented by the key contributions of Zahra (2003), Fernandez \& Nieto (2005), and George et al. (2005), is closely linked to the RESOURCE-BASED VIEW cluster. This stream of research explores the key resources and capabilities that influence family firms to internationalize. Through the RBV, we can see that the competitive advantage of firms relies upon their unique resources. In family firms, these resources are represented by the familiness, i.e. "the unique bundle of resources a particular firm has because of the system's interaction between the family, its individual members, and the business" (Habbershon \& Williams, 1999: 11). These resources are "physical capital resources (plant, raw materials, location, cash, access to capital, intellectual property), human capital resources (skills, knowledge, training, relationships), organizational capital resources (competencies, controls, policies, culture, information, technology), and process capital resources (knowledge, skills, disposition, and commitment to communication, leadership, and the team)" (Habbershon \& Williams, 1999: 11). However, considering the internationalization sphere, previous academic literature has mainly investigated the lack of financial resources and managerial capabilities when explaining why family firms internationalize less.

The thematic cluster of DIVERSIFICATION DECISIONS is highly dependent on BEHAVIOURAL AGENCY THEORY - a refinement of AGENCY THEORY. The reasons for this lie in the fact that diversification decisions are risky and endanger not only the firm, but also the family. According to behavioural agency theory, organizational risk behaviour is explained by the "goals and the risk preferences of those who directly make decisions on behalf of the organization" (Kumeto, 2015). Managers tend to be loss averse. Specifically, they tend to choose strategic options 
that avoid loss to their personal wealth (i.e. their reference point). However, in the context of a family firm, the behavioural agency theory assumes some specificities. As summarized by Kumeto (2015), in family firms, we do not find the separation between principal (owner) and agent (manager), and the managers' personal wealth is not only a financial wealth but, above all, a non-financial one. Consequently, family firms are characterized by a willingness to avoid losses of socioemotional wealth and so, when the firm is governed by family members, the firm is less likely to put the family firm at risk through internationalization, as the maintenance of socioemotional wealth is more important. It is not surprising then that, when the board of directors is made up of non-family external managers, the firms internationalize more (Arregle et al., 2012). The links between these two clusters also shed light on the fact that family firms choose domestic rather than international markets. To lower the associated risks, family firms tend to choose culturally close regions (Gomez-Mejia et al., 2010).

The thematic cluster of NETWORKS clearly draws on the SOCIAL CAPITAL cluster of cocitations. An interesting example explaining the link between these two clusters is represented by Kontinen \& Ojala (2010b), who investigate the ways in which psychic distance affects the internationalization process, foreign market entry, and the choice of entry mode of family firms through multiple case studies. Their findings suggest that family firms tend to choose psychically close countries and proceed in stages, initially favouring indirect entry modes. In addition to this, family firms use distance-bridging factors, such as recruiting skilled local employees. The relationship between these two clusters sheds light on the importance of investigating intra- and interfirms' relationships. Family business scholars have emphasized the importance of organizational social capital (e.g. Arregle et al., 2007).

The thematic cluster of INTERNATIONAL ENTREPRENEURIAL ORIENTATION is mainly linked to STEWARDSHIP and FAMILY FIRMS' IDIOSYNCRACIES. Previous research has analysed the speed of internationalization (Cesinger, Boucken, Fredrch, \& Kraus, 2014) and the mediating role of IEO when it comes to the involvement of non-family members in terms of governance and internationalization pace (Calabrò, Campopiano, Basco, \& Pukall, 2017). According to the stewardship theory, organizational members develop collectivistic attitudes that materialize in "a comprehensive strategic decision making, participative governance, long-term orientation, employee human capital and family-to-firm unity" (Eddleston, Kellermanns, \& Zellweger, 2012: 350).

The thematic cluster of RESIDUAL CONTRIBUTIONS mainly draws on the FAMILY FIRMS' IDIOSYNCRACIES and SOCIAL CAPITAL contributions. Theoretical contributions are linked to the specificities of family firms in terms of ownership, governance, and management, as 
represented by Sciascia, Mazzola, Astrachan, \& Pieper (2012), who stress the greater importance of family involvement over family ownership.

\subsection{An integrative framework in studying internationalization of family firms}

Building on the analysis presented so far, we propose an integrative framework that reorganizes the thematic clusters and the theoretical roots, as developed in previous sections, in order to provide guidance for future research. Based on the main links between bibliographic coupling and co-citation analysis (Section 4.3), we identify research paths based on a framework that bridges literature on family firms and internationalization. Specifically, Figure 10 shows the theoretical roots (dashed lines) distinguishing between the theories that are mainly linked to family firm literature (left hand side) and those mainly related to internationalization literature (right hand side). At the core of Figure 10 , the thematic communities emerging from the bibliographic coupling are shown. This framework helps scholars to trace the paths followed by research communities up to now and, consequently, spot the gaps and identify future research questions worthy of investigation. In other words, how has the internationalization of family firms been seen so far? What should future research investigate further, and how?

Before proceeding with an overview of potential paths for future research, it is important to highlight that internationalization can take several forms. Most studies have examined export intensity (i.e. the internationalization scale) as their main variable, while neglecting to research composite measures, such as the entropy index that considers "both the number of geographic segments in which a family firm operates and the relative importance of each geographic segment over total family firm sales" (Sanchez-Bueno \& Usero, 2014: 1315). In particular, the concept of internationalization speed (or pace) has been scantly considered. The reasons for this lie in the fact that contributors have usually drawn inspiration from the Uppsala Model, which considers internationalization to be a slow process. Indeed, the internationalization model adopted, i.e. Uppsala, Dunning, International Entrepreneurship, and Uppsala revisited, influences which aspects of internationalization have been investigated. As shown, several contributions have relied upon the Uppsala Model and, more recently, on the Uppsala revised (Pukall \& Calabrò, 2014). In this paper, we propose that internationalization should be seen from a different angle that simultaneously considers all of the three 'S's: the scale, the scope (i.e. the number of countries in which the firm internationalizes), and the speed through which internationalization happens.

Figure 10. The research paths of internationalization of family firms 


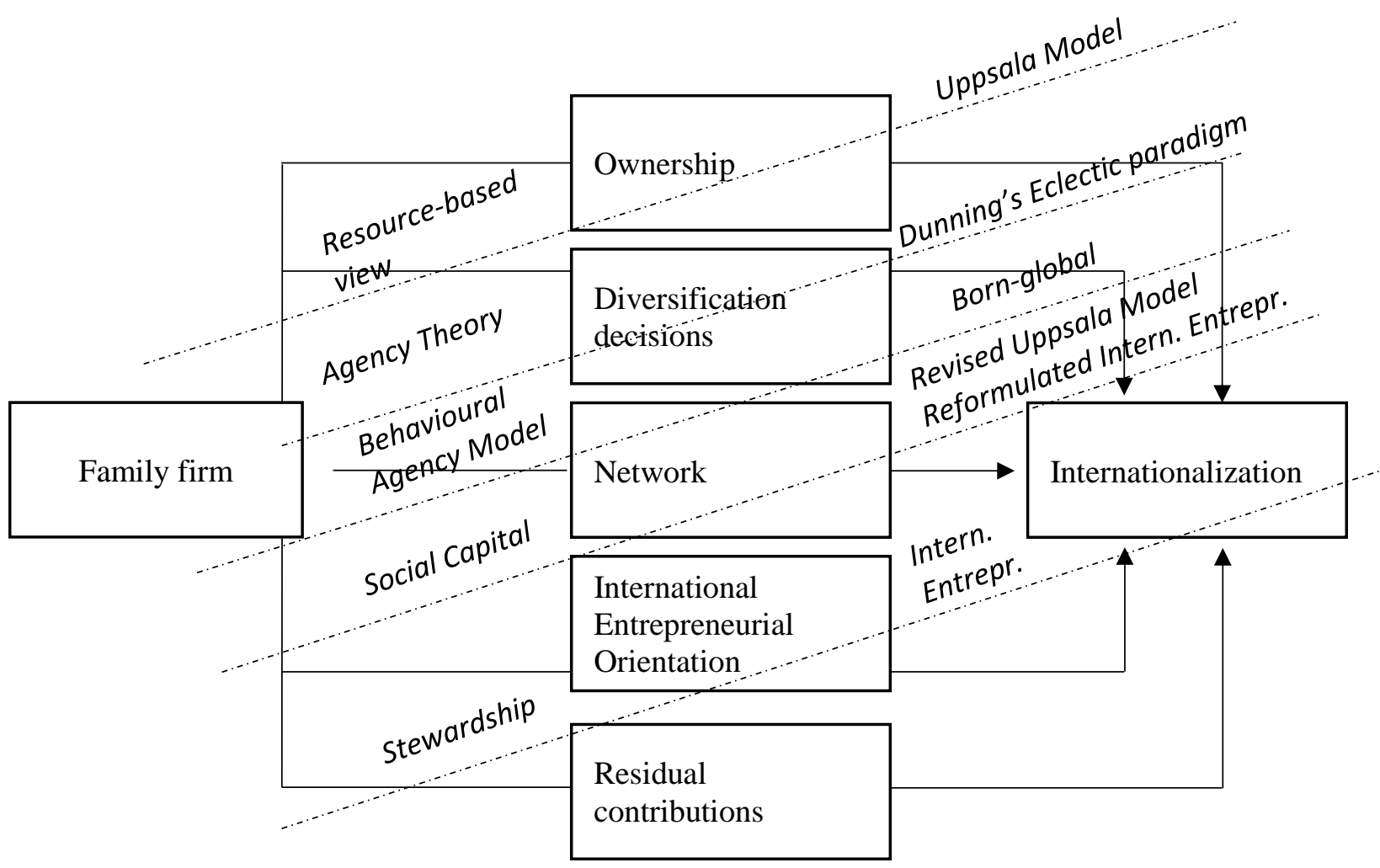

We will now proceed with our recommendations for future research paths. We start our discussion by examining the OWNERSHIP thematic cluster. As seen in the previous section, this cluster relies heavily upon the RESOURCE-BASED VIEW and has adopted the UPPSALA MODEL as its main internationalization lens. Indeed, according to the Uppsala Model, firms tend to progress in different stages, from more indirect investments (e.g. throughout exports) to more direct ones (e.g. via overseas production). Up until now, exports have been the main area of focus and, as such, a deeper understanding of the factors explaining direct investments is needed. We posit that the resource-based view could help to answer this question. By looking deeper into seminal research contributions regarding family firms that move from the resource-based view, we can see that several elements have been largely underestimated. The resource-based view could predict that family firms, with their unique resources, should outperform their non-family counterparts. Therefore, looking at the empirical evidence that suggests that family firms internationalize less than their non-family counterparts, a question arises: have scholars identified the right resources that could lead to higher levels of internationalization? At the moment, academic attention has been mainly focused on financial resources (e.g. Graves \& Thomas, 2006), but we know that family firms possess unique resources; namely human capital, social capital, patient capital, and survivability capital, along with the attributes of their governance structure (Sirmon \& Hitt, 2003). With the exception of social capital, which emerges as the main theoretical root of the network cluster, there is a paucity of contributions concerning other resources. For example, the role of patient capital and survivability 
capital needs further investigation. An exception is represented by Segaro (2012), who examined the relationship between ownership, governance, TMT, and internationalization. In her conceptual model, patient and survivability capital are not shown to determine internationalization per se, but they are instead mediated by strategic flexibility. Alongside other colleagues, the same author also proposed an empirical examination (Segaro et al. 2014), but one without considering patient or survivability capital roles. We argue that, due to the fact that family patient capital influences people's willingness to wait for longer term results, while survivability capital is important when family firms face resource constraints (survivability capital represents the personal capital of the family), both may influence internationalization processes in terms of speed and entry modes. Indeed, some case studies have introduced the importance of patient capital when it comes to the viability of the firm in the long run (e.g. Jones, Ghobadian, O'Reagan \& Antcliff, 2013), but the evidence is not very clear. Consequently, we recommend that future researchers investigate:

Research Gap 1: What is the role of family patient capital in explaining internationalization?

Research Gap 2: What is the role of family survivability capital in explaining internationalization?

Furthermore, the impact of marketing-related concepts, such as that of the family brand on the internationalization performance of family firms, is unknown. From recent research, we have deduced that one of the unique resources of family firms is their brand, and that they adopt different branding strategies (Micelotta \& Raynard, 2011). Moreover, a family brand needs to be managed during succession (e.g. Casprini, Melanthiou, Pucci, \& Zanni 2019). The papers analysed do not reveal insights into the ways in which family firms use their brands in internationalization processes and outcomes. One exception is shown in a recent paper by Denicolai, Hagen, Zucchella \& Cubero Dudinskaya (2019), who focused on the relationship between trademark acquisition and international performance (measured in terms of overseas sales over total sales) and the moderating role of family ownership. They found that high levels of ownership negatively moderate the trademark acquisition/internationalization performance relationship (which is positive). Their study is also interesting as it identifies the need for a better understanding of "the informal and tacit side of reputation and recognition" (p. 247). Hence, further research questions could be:

Research Gap 3: What is the role of the family brand in internationalization?

Research Gap 4: How do successors manage the family brand through the process of internationalization?

Due to the heterogeneity of OWNERSHIP, we recommend that future researchers consider the different types of ownership present in family firms. Specifically, future research should better 
distinguish between family-influenced and family-controlled firms (see D’Angelo, Majocchi, \& Buck, 2016). For example, researchers could examine the ways in which different ownership levels influence the disposal of specific resources throughout the internationalization process.

Research Gap 5: How does family ownership heterogeneity influence family resource disposal for internationalization?

The second thematic cluster relates to DIVERSIFICATION DECISIONS and relies on AGENCY THEORY and DUNNING'S ECLECTIC PARADIGM as well as the BEHAVIOURAL AGENCY MODEL and BORN-GLOBAL. This is not surprising, as agency theory and behavioural agency models are strongly linked (for a review see Kumeto, 2015) as a result of the fact that a behavioural agency model is born in reaction to an agency theory. The highly fragmented internationalization theories adopted impede scholars in developing a homogenous research path. The Dunning's eclectic paradigm and the born-global model stem from very different perspectives; the former is focused on ownership, location, and internalization advantages, and the latter is focused on the four main business strategies, namely global technological competence, unique product development, quality of focus, and leveraging foreign distributor competencies (Knight \& Cavusgil, 2004). Hence, the research community focusing on DIVERSIFICATION DECISIONS should consider two main paths. On the one hand, they should focus on the impact of governance structure (principal-agent) on the different diversification decisions based on ownership, locational, and internalization advantages. On the other hand, they should look at the impact of socioemotional wealth on the decision to internationalize early. This could be particularly interesting in relation to innovation. Innovation in family firms is a very recent field of research. As shown in our analysis, innovation and internationalization have been mainly considered within the scope of the firms' performance or as a corporate venturing activity (Calabrò, Minola, Campopiano, \& Pukall, 2016b), but some innovation activities, such as collaborative projects, might have an influence on the internationalization process and the overall decision to internationalize at the very beginning. Additionally, a recent contribution by Zahra (2019) shows that little is known about the relationship between technological capabilities and internationalization. According to him, technological capabilities “frequently exceed the firm's $R \& D$ activities; they are nurtured also by company's other investments made in acquiring technological knowledge through open innovation" (p. 5). He argues that the effect of technological capabilities on internationalization scales and scopes is dependent on whether or not firms are able to leverage on other intangible resources. More precisely, he focuses on two types of organizational social capital - general, i.e. deriving from relationships with other companies in general, and specific, i.e. deriving from relationships with other companies or third parties located in the target region. Moving on from this contribution, we assert that further 
investigations should be made with respect to technological capabilities. In particular, we recommend that further researchers focus on digitalization and the ways in which digital technologies are adopted and used for internationalization. Therefore, we recommend that future researchers consider:

Research Gap 6: How do innovation activities influence born-global family firms?

Research Gap 7: How do family and non-family firms adopt digital technologies into their internationalization processes?

The third research path looks at the internationalization of family firms throughout NETWORKS. As shown, this stream of research relies on SOCIAL CAPITAL and has mainly adopted the REVISED UPPSALA MODEL and the REFORMULATED definition of INTERNATIONAL ENTREPRENEURSHIP. Indeed, the community's observation of the internationalization of a family firm, from a network perspective, should better distinguish the concept of social capital in families and firms, as well as examine the potential ways to bond and bridge social capital (Kontinen \& Ojala, 2011b). As previous studies note (Arregle et al., 2007), in family firms, there are at least two forms of social capital: that of the family and that of the firm. However, this distinction has not been considered. As Arregle et al. (2007) note, social capital can be seen from a content perspective (i.e. looking at its structural, relational, and cognitive dimensions), and from a process perspective (what they look at). For example, a family's social capital could be particularly relevant when exploiting certain foreign countries' networks or when selecting one specific entry mode over another. Thus:

Research gap 8: How does family and organizational social capital affect internationalization in family firms?

The three dimensions of social capital (structural, relational, and cognitive) have been scantly investigated, even though they could assist in explaining the internationalization process. From related work on the topic of social capital in family firms, we know that a family's social capital gathers value creation across generations through different mechanisms (Salvato \& Melin, 2008); bridging social capital and external relationships, thus improving trust and reputation, and bonding social capital with internal family ties through the trust, norms, obligations, and expectations of family members. The bridging of social capital leads family firms to obtain cost advantages and exploration opportunities, while the bonding of social capital might improve the family's cohesiveness and the family members' human capital. Consequently, we think that researchers should investigate:

Research gap 9: How do structural, relational, and cognitive dimensions of social capital influence the internationalization process of family firms?

Research gap 10: What are the roles of bridging and bonding social capital and how do they interplay in the internationalization process of family firms? 
The fourth research stream is that of INTERNATIONAL ENTREPRENEURIAL ORIENTATION, which is mainly drawn from literature concerning STEWARDSHIP, INTERNATIONAL ENTREPRENEURSHIP, and FAMILY FIRMS' IDIOSYNCRACIES. From the seminal work of Davis et al. (1997), we know that stewardship theory is distinct from agency theory in terms of both psychological and situational mechanisms. This is not the right place to discuss them, but we believe that the field of research on the internationalization of family firms would benefit from further investigation into stewardship theory. Stewardship theory could help to explain why some family firms have internationalized and continue to internationalize better than others. In the family firms in which the family gives intrinsic motivations; encourages external managers to accept the organization's mission, vision, and objectives; and diffuses the use of personal rather than institutional power, stewards are more likely to emerge (Davis et al., 1997). Stewards are particularly crucial in uncertain environments, such as during times of innovation and internationalization, and yet we know little about the role of stewards in the internationalization process. This is particularly important when considering international entrepreneurship literature, according to which there are some businesses that are born-global. Indeed, some family firms begin expanding internationally from the outset. This could be due to their innovative culture, their knowledge, and their capabilities (Knight \& Cavusgil, 2004) and stewards could assist in explaining how born-global family firms emerge and perpetuate. Of course, retrospective case studies could be particularly useful in identifying the ways in which principal/steward relationships facilitate early internationalization. Specifically, we think that future research should better investigate the role of individual characteristics, such as education (Ramon-Llorens, Garcia-Meca, \& Durendez 2017; Saeed et al., 2017). In particular, we believe that a promising area of research would be that of gender. Entrepreneurship-related research has looked at the influence of women on specific activities, such as funding (e.g. Marlow \& Patton, 2005). Consequently, we propose:

Research Gap 11: How do family firms that are controlled and/or managed by women internationalize compared to those controlled and/or managed by men?

Additionally, as the recent review of Pukall \& Calabrò (2014) notes, what is important and should be better investigated is the differentiation between scenarios in which performance is below or above aspirations. In these cases, the preservation of socioemotional wealth may act as enabler or an obstacle to internationalization. The family dynamic pertains to the fact that family firms have to overcome a succession period, which is often very challenging (Fernandez \& Nieto, 2005). In addition to this, because family firms have lower agency costs than non-family firms, there could be a misalignment in objectives as the number of generations involved increases. It would therefore be 
interesting to explore the link between internationalization and non-financial goals. Hence, future researchers should address:

Research Gap 12: How and to what extent does the preservation of non-financial goals (e.g. family harmony) influence internationalization?

Research Gap 13: How do family firms' critical episodes (e.g. succession, divorce, newborn child) influence internationalization?

Finally, in analysing the residual contributions, we observe that an interesting avenue of research may be linked to investigating which entry mode (rather than exporting activities) is preferred and under what conditions, especially in the context of emerging markets. Indeed, due to their willingness to preserve socioemotional wealth and their tendency to avoid risk, family firms may prefer indirect entry modes. However, we suggest that family firms could be particularly efficient with regards to mergers and acquisitions as well and may prefer to create alliances or go into joint ventures with other family firms. Initial empirical evidence, based on multinational enterprises investing in Italian companies and adopting a transaction cost perspective, show that joint ventures are preferred when both the investing firm and the local firm are family firms (Sestu \& Majocchi, 2018). However, we think that interesting insights could derive from the behavioural agency model: in order to preserve their socioemotional wealth, family firms should deal with other family firms as they both share the same goals.

Research Gap 14: Under which circumstances do family firms prefer one entry model over others?

\section{Conclusion}

This paper provides an in-depth analysis of the intellectual core of the internationalization of family firms, complementing extant research (Arregle et al., 2017; Kontinen \& Ojala, 2010a; Pukall \& Calabrò, 2014). Contributions up to 2019 were considered and analysed, and five thematic clusters were developed through bibliographic coupling, which underlined the main themes; namely ownership, diversification decisions, networks, international entrepreneurial orientation, and residual contributions. The co-citation analysis of the cited references identified seven main theoretical roots: (i) the Resource-Based View and Uppsala Model; (ii) Agency Theory and Dunning's Eclectic paradigm; (iii) Behavioural Agency Model (specifically socioemotional wealth) and Born-Global; (iv) Social Capital, Revised Uppsala, and Reformulated International Entrepreneurship; (v) Stewardship theory and International Entrepreneurship; (vi) Family Firms' Idiosyncrasies, and (vii) Emerging Markets. 
This study contributes to family firm internationalization research in three ways. Firstly, it consolidates existing papers published on the topic up until 2019, thus improving the time window considered in previous review efforts and providing an up-to-date overview of this important research stream. In doing this, we are able to document the continued growth of this important research field and highlight the growing diversity of the literature therein in terms of research themes studied and theoretical perspectives used. Secondly, the study relies on rigorous bibliometric techniques, namely bibliometric coupling and co-citation analysis. This enables us to overcome the inherent limitations of qualitative reviews previously conducted on the topic and more systematically asses the variety of research themes and theoretical roots within this field of research, as well as the links between them. Our analysis generated a wealth of novel insights concerning the evolution of family firm internationalization research. Specifically, it identifies established research paths that explore specific research topics using coherent theoretical perspectives. At the same time, it reveals new unchartered research paths that represent fruitful areas for future research. Thirdly, based on our analyses, we develop an integrative framework that puts forward important research gaps and future research questions, seeking to expand the scope of family firm innovation research to new, largely unexplored research paths. In summary, compared to previous qualitative literature reviews, this study presents a more comprehensive, updated, and detailed overview of existing research on family firm innovation, which can be used as a guiding framework by researchers who approach this field of study. The most cited previous literature reviews have either reviewed the background theories adopted (Kontinen \& Ojala, 2010a) or focused on specific theoretical frameworks, such as the socioemotional wealth and revised Uppsala Model (Pukall \& Calabrò, 2014) and institution-based views (Arregle et al., 2017). Our work builds on and extends these efforts, providing a broader framework capable of guiding scholars when approaching family firms' internationalization from different points of interest and alternate theoretical perspectives.

This study does have limitations. The first limitation is inherent to the methodology used. While we have considered all contributions from all fields of research, the analysis could be extended by including more keywords linked to internationalization. A second limitation lies in the analysis of our results. While bibliometric methods help reduce subjectivity, we cannot completely rule out the possibility that the analysis of the intellectual core and the theoretical roots could be bounded by some interpretative biases. Of course, this limitation is mitigated when involving additional, external researchers. The research could also be subject to criticism as five previous literature reviews on the topic already exist. Nonetheless, this work marks an important step. Firstly, we argue that four of the five previous literature reviews solely focus on specific aspects, such as a broad overview (Kontinen \& Ojala, 2010a), the role of socioemotional wealth and revised Uppsala Model (Pukall \& Calabrò, 
2014), the influence of agency and stewardship theories (Marìn-Anglada et al., 2014), and the role of institutional context (Arregle et al., 2017). Secondly, our paper shows limitations because of the methodology adopted by Casillas and Moreno-Menendez (2017), whose paper presents an interesting framework that describes how international business and family business disciplines may intertwine. They identify six gaps: the national culture, the corporate governance, the risk attitude, the objectives, the networks, and the timing of internationalization, thus providing a framework that links multiple spheres of research. However, they move from a systematic review and adopt Melin's (1992) framework when analysing the papers and research gaps, thus constraining their framework into three main activities (entry modes, transactions, and coordination mechanisms) and two organizational boundaries (within or between organizations). The framework that we provide is broader and thus offers further insight. For example, we cite the roles of innovation and brand, which are not addressed in the frameworks of Casillas \& Moreno-Menendez (2017). Moreover, our paper clearly considers the several internationalization schools of thought (Uppsala, Dunning, Uppsala revised, international entrepreneurship, reformulated international entrepreneurship, born-global), thus providing a more nuanced contribution.

In the future, our framework can be used to further develop research on the internationalization of family firms. Furthermore, as the field is flourishing, we anticipate the adoption of a combination of several perspectives, as well as the blending of qualitative and quantitative methodologies. In particular, we think that our framework can be used by both larger and smaller family firms as it outlines the key ingredients needed to assist academic scholars in converging towards comparable analyses, while simultaneously allowing managers to identify the challenges and limitations of their firms.

\section{References}

Abdellatif, M., Amann, B., \& Jaussaud, J. (2010). Family versus nonfamily business: a comparison of international strategies. Journal of Family Business Strategy, 1(2), 108-116.

Adler P.S. \& Kwon S.-W. (2002). Social capital: prospects for a new concept. Academy of Management Review, 27(1), 17-40.

Alessandri, T. M., Cerrato, D., \& Eddleston, K. A. (2017). The mixed gamble of internationalization in family and nonfamily firms: the moderating role of organizational slack. Global Strategy Journal, 8, 46-72. 
Appio, F. P., Martini, A., Massa, S., \& Testa, S. (2017). Collaborative Network of Firms: Antecedents and State-of-the-Art Properties. International Journal of Production Research, 55(7), 21212134.

Arregle, J.-L., Duran, P., Hitt, M.A., \& van Essen, M. (2017). Why is family firms' internationalization unique? A meta-analysis. Entrepreneurship: Theory and Practice, 41(5), 801-831.

Arregle, J., Hitt, M., \& Mari, I. (2019). A missing link in family firms' internationalization research: Family structures. Journal of International Business Studies, 50(5), 809-825.

Arregle, J. -L., Hitt, M. A., Sirmon, D. G., \& Very, P. (2007) The development of organizational social capital: attributes of family firms. Journal of Management Studies, 44(1), 73-95.

Arregle, J. -L., Naldi, L., Nordqvist, M., \& Hitt, M. A. (2012). Internationalization of familycontrolled firms: a study of the effects of external involvement in governance. Entrepreneurship: Theory and Practice, 36(6), 1115-1143.

Astrachan, J. H., Klein, S. B., \& Smyrnios, K. X. (2002). The F-PEC scale of family influence: a proposal for solving the family business definition problem. Family Business Revie, 15(1), 4558.

Bammens, Y., Voordeckers, W., \& Van Gils, A. (2008). Boards of directors in family firms: a generational perspective. Small Business Economics, 31(2), 163-180.

Barney, J. (1991). Firm resources and sustained competitive advantage. Journal of Management, 17(1), 99-120.

Berrone, P., Cruz, C., \& Gomez-Mejia, L. R. (2012). Socioemotional wealth in family firms: theoretical dimensions, assessment approaches, and agenda for future research. Family Business Review, 25, 258-279.

Beugeldsdijk, S., Smeets, R., \& Zwinkels, R. (2008). The impact of horizontal and vertical FDI on host's country economic growth. International Business Review, 17(4), 452-472.

Boellis, A., Mariotti, S., Minichilli, A., \& Piscitello, L. (2016). Family involvement and firms' establishment mode choice in foreign markets. Journal of International Business Studies, 47, 929-950.

Borgatti, S. P. (2002). Netdraw Network Visualization. Harvard, MA: Analytic Technologies.

Borgatti, S. P., Everett, M. G., \& Freeman, L. C. (2002). Ucinet 6 for Windows: Software for Social Network Analysis. Harvard, MA: Analytic Technologies.

Boyack, K. W. \& Klavans, R. (2010). Co-citation analysis, bibliographic coupling, and direct citation: Which citation approach represents the research front most accurately? Journal of the American Society for Information Science and Technology, 61(12), 2389-2404. 
Burt, R. S. (1997). The contingent value of social capital. Administrative Science Quarterly, 42(2), 339-365.

Burt, R. S. (2000). The network structure of social capital. Research in Organizational Behavior, 22, $345-423$.

Cabrera-Suarez, K., Saa-Perez, P., \& Garcia-Almeida, D. (2001). The succession process from a resource-and knowledge-based view of the family firm. Family Business Review, 14(1), 37-48.

Calabrò, A., Brogi, M., \& Torchia, M. (2016a). What does really matter in the internationalization of small and medium-sized family businesses? Journal of Small Business Management, 54(2), 679-696.

Calabrò, A., Campopiano, G., Basco, R., \& Pukall T. (2017). Governance structure and intenationalization of family-controlled firms: the mediating role of international entrepreneurial orientation. European Management Journal, 35(2), 238-248.

Calabrò, A., Minola, T., Campopiano, G., \& Pukall T. (2016b). Turning innovativeness into domestic and international corporate venturing: the moderating effect of high family ownership and influence. European Journal of International Management, 10(5), 505-533.

Calabrò, A. \& Mussolino, D. (2013). How do boards of directors contribute to family SME export intensity? The role of formal and informal governance mechanisms. Journal of Management and Governance, 17(2), 363-403.

Calabrò. A., Torchia, M., Pukall, T., \& Mussolino, D. (2013). The influence of ownership structure and board strategic involvement on international sales: the moderating effect of family involvement. International Business Review, 22, 509-523.

Carpenter, M. A. \& Fredrickson, J. A. (2001). Top management teams, global strategic posture, and the moderating role of uncertainty. Academy of Management Journal, 44(3), 533-545.

Casillas, J. C. \& Moreno-Menéndez, A. M. (2017). International Business and Family Business: Potential Dialogue between Disciplines. European Journal of Family Business, 7, 25-40.

Casillas, J. C., Moreno, A. M., \& Barbero, J. L. (2010). A configurational approach of the relationship between entrepreneurial orientation and growth of family firms. Family Business Review, 23(1), 27-44.

Casprini, E., Melanthiou, Y., Pucci, T., \& Zanni, L. (2019). Managing founder-based brand identity during succession. Journal of Brand Management. DOI: https://doi.org/10.1057/s41262-01900161-x.

Cerrato, D. \& Piva, E. (2012). The internationalization of small and medium-sized enterprises: the effect of family management, human capital and foreign ownership. Journal of Management and Governance, 16(4), 617-644. 
Cesinger, B., Bouncken, R., Fredrich, V., \& Kraus, S. (2014). The alchemy of family enterprises' internationalisation: Dexterous movers or prodigal laggards? European Journal of International Management, 8(6), 671-696.

Chua, J. H., Chrisman, J. J. \& Sharma, P. (1999). Defining the family business by behaviour. Entrepreneurship: Theory and Practice, 23(4), 19-39.

Coleman, J. S. (1988). Social capital in the creation of human capital. American Journal of Sociological Review, 94, 1-95.

Covin, J. G. \& Miller, D. (2014). International entrepreneurial orientation: conceptual considerations, research themes, measurement issues, and future research directions. Entrepreneurship: Theory and Practice, 38(1), 11-44.

D’Angelo, A., Majocchi, A., \& Buck, T. (2016). External managers, family ownership and the scope of SME internationalization. Journal of World Business, 51, 534-547.

Dabić, M., Maley, J., Dana, L. P., Novak, I., Pellegrini, M. M., \& Caputo, A. (2019). Pathways of SME internationalization: a bibliometric and systematic review. Small Business Economics, 121.

Davis, P. S. \& Harveston, P. D. (2000). Internationalization and organizational growth: the impact of internet usage and technology involvement among entrepreneur-led family businesses. Family Business Review, 13(2), 107-120.

Davis, J. H., Schoorman, F. D., \& Donaldson, L. (1997). Toward a stewardship theory of management. Academy of Management Review, 22(1), 20-47.

Delbufalo, E., Poggesi, S., \& Borra, S. (2016). Diversification, family involvement and firm performance: empirical evidence from Italian manufacturing firms. Journal of Management Development, 35(5), 663-680.

Denicolai, S., Hagen, B., Zucchella, A., \& Cubero Dudinskaya, E. (2019). When less family is more: Trademark acquisition, family ownership, and internationalization. International Business Review, 28(2), 238-251.

Dunning, J. H. (1981). International production and the multinational enterprise. London: George Allen \& Unwin.

Dunning, J. H. (1988). The eclectic paradigm of international production: a restatement and some possible extensions. Journal of International Business Studies, 19(1), 1-31.

Eberhard, M. \& Craig, J. (2013). The evolving role of organisational and personal networks in international market venturing. Journal of World Business, 48(3), 385-397. 
Eddleston, K. A., Kellermanns, F. W., \& Zellweger, T. M. (2012). Entrepreneurial behaviour of family firms: does the stewardship perspective explain differences? Entrepreneurship: Theory \& Practice, 36(2), 347-367.

Eddleston, K., Sarathy, R., \& Banalieva, E. R. (2019). When a high-quality niche strategy is not enough to spur family-firm internationalization: the role of external and internal contexts. Journal of International Business Studies, 50(5), 783-808.

Eisenhardt, K. M. (1989). Building theories from case study research. Academy of Management Review, 14(4), 532-550.

Elango, B. (2019). A bibliometric analysis of franchising research (1988-2017). The Journal of Entrepreneurship, 28(2), 223-249.

Ellis, P. D. (2000). Social ties and foreign market entry. Journal of International Business Studies, 31(3), 443-469.

Erdener, C. \& Shapiro, D. M. (2005). The internationalization of Chinese family enterprises and dunning's eclectic MNE paradigm. Management and Organization Review, 1(3), 411-436.

Fernandez, Z., \& M. J. Nieto (2005). Internationalization Strategy of Small and Medium-Sized Family Businesses: Some Influential Factors. Family Business Review, 18(1), 77-89.

Fernandez, Z. \& Nieto, M. J. (2006). Impact of ownership on the international involvement of SMEs. Journal of International Business Studies, 37(3), 340-351.

Gallo, M. A. \& Pont, C. G. (1996). Important factors in family business internationalization. Family Business Review, 9(1), 45-59.

Gallo, M. A. \& Sveen, J. (1991). Internationalizing the family business: facilitating and restraining factors. Family Business Review, 4(2), 181-190.

Gedajlovic, E., Carney, M., Chrisman, J. J., \& Kellermanns, F. W. (2012). The adolescence of family firm research: Taking stock and planning for the future. Journal of Management, 38(4), 10101037.

George, G., Wiklund, J., \& Zahra, S.A. (2005). Ownership and the internationalization of small firms. Journal of Management, 31(2), 210-233.

Gomez-Mejia, L. R. (1988). The role of human resources strategy in export performance: a longitudinal study. Strategic Management Journal, 9(5), 493-505.

Gomez-Mejia, L. R., Cruz, C., Berrone, P., \& De Castro, J. (2011). The bind that ties: socioemotional wealth preservation in family firms. Academy of Management Annals, 5, 653-707.

Gomez-Mejia, L. R., Haynes, K. T., Nunez-Nickel, M., Jacobson, K. J., \& Moyano-Fuentes, J. (2007). Socioemotional wealth and business risks in family-controlled firms: evidence from Spanish olive oil mills. Administrative Science Quarterly, 52(1), 106-137. 
Gomez-Mejia, L. R., Kintana, M. L. \& Makri, M., (2003). The determinants of executive compensation in family-controlled public corporations. Academy of Management Journal, 46 (2), 226-237.

Gomez-Mejia, L. R., Makri, M. \& Kintana, M. L. (2010). Diversification decisions in familycontrolled firms. Journal of Management Studies, 47(2), 223-252.

Granovetter, M. (1973). The strength of weak ties. American Journal of Sociology, 78, 1360-1380.

Graves, C. \& Thomas, J. (2004). Internationalisation of the Family Business: A Longitudinal Perspective. International Journal of Globalisation and Small Business, 1(1), 7-27.

Graves, C. \& Thomas, J. (2006). Internationalization of Australian Family Businesses: A Managerial Capabilities Perspective. Family Business Review, 19(3), 207-224.

Habbershon, T. G. \& Williams, M. L. (1999). A resource-based framework for assessing the strategic advantages of family firms. Family Business Review, 12(1), 1-25.

Habib, R., \& Afzal, M. T. (2019). Sections-based bibliographic coupling for research paper recommendation. Scientometrics, 119(2), 643-656.

Hamill, J. \& Wersun, A. (1996). Joint ventures in Russia: the experience of two small companies. Journal of East-West Business, 1(4), 17-34.

Hennart, J. F., Majocchi, A., \& E. Forlani (2017). The myth of the stay-at-home family firm: How family-managed SMEs can overcome their internationalization limitations. Journal of International Business Studies, in press.

Hillman, A. \& Dalziel, T. (2003). Boards of directors and firm performance: integrating agency and resource dependence perspectives. Academy of Management Review, 28(3), 383-396.

Hitt, M. A., Hoskinson, R. E. \& Kim, H. (1997). International Diversification: Effects on Innovation and Firm Performance in Product-Diversified Firms. Academy of Management Journal, 40(4), $767-798$.

Holt, D. T. (2012). Strategic decisions within family firms: understanding the controlling family's receptivity to internationalization. Entrepreneurship: Theory \& Practice, 36(6), 1145-1151.

Iwami, S., Ojala, A., Watanabe, C., \& Neittaanmäki, P. (2020). A bibliometric approach to finding fields that co-evolved with information technology. Scientometrics, 122, 3-21, DOI: https://doi.org/10.1007/s11192-019-03284-9.

Johanson, J. \& Vahlne, J. E. (1977). The internationalization process of the firm: a model of knowledge development and increasing foreign market commitments. Journal of International Business Studies, 8(1), 23-32. 
Johanson, J., \& Vahlne, J. E. (2009). The Uppsala internationalization process model revisited: from liability of foreignness to liability of outsidership. Journal of International Business Studies, 40(9), 1411-1431.

Jones, O., Ghobadian, A., O’Reagan, N., \& Antcliff, V. (2013). Dynamic capabilities in a sixthgeneration family firm: entrepreneurship and the Bibby line. Business History, 55(6), 910-941.

Kajikawa, Y., Ohno, J., Takeda, Y., Matsushima, K., \& Komiyama, H. (2007). Creating an academic landscape of sustainability science: An analysis of the citation network. Sustainability Science, 2(2), 221-231, DOI: https ://doi.org/10.1007/s1162 5-007-0027-8.

Knight, G. \& Cavusgil, S. T. (2004). Innovation, organizational capabilities, and the born-global firm. Journal of International Business Studies, 35, 124-141.

Kontinen, T. \& Ojala, A. (2010a). The internationalization of family businesses: a review of extant research. Journal of Family Business Strategy, 1(2), 97-107.

Kontinen, T. \& Ojala, A. (2010b). Internationalization pathways of family SMEs: psychic distance as a focal point. Journal of Small Business and Enterprise Development, 17(3), 437-454.

Kontinen, T. \& Ojala, A. (2011a). International opportunity recognition among small and mediumsized family firms. Journal of Small Business Management, 49(3), 490-514.

Kontinen, T. \& Ojala, A. (2011b). Social capital in relation to the foreign market entry and post-entry operations of family SMEs. Journal of International Entrepreneurship, 9(2), 133-151.

Kraus, S., Menshing, H., Calabrò, A., Cheng, C.-F. \& Filser, M. (2016). Family firm internationalization: a configurational approach. Journal of Business Research, 69(11), 5473 5478.

Kumeto, G. (2015). Behavioural agency theory and the family business, in Nordqvist, M., Melin, L., Waldkirch, M., \& Kumeto, G. (eds.), Theoretical perspectives on family businesses (pp. 7898). Cheltenham: Edward Elgar Publishing.

Kuo, A., Kao, M. -S., Chang, Y. -C., \& Chiu, C. -F. (2012). The influence of international experience on entry mode choice: difference between family and non-family firms. European Management Journal, 30(3), 248-263.

Laufs, K. \& Schwens, C. (2014). Foreign market entry mode choice of small and medium-sized enterprises: a systematic review and future research agenda. International Business Review, 23(6), 1109-1126.

Linnenluecke, M. K. (2017). Resilience in business and management research: a review of influential publications and a research agenda. International journal of Management Reviews, 19, 4-30. 
López-Duarte, C., González-Loureiro, M., Vidal-Suárez, M. M. \& González-Díaz, B. (2016). International strategic alliances and national culture: mapping the field and developing a research agenda. Journal of World Business, 51, 511-524.

Lumpkin, G. T. \& Dess, G. G. (1996). Clarifying the entrepreneurial orientation construct and linking it to performance. Academy of Management Review, 21(1), 135-172.

Majocchi, A., D’Angelo, A., Forlani, E., \& Buck, T. (2018). Bifurcation bias and exporting: Can foreign work experience be an answer? Insight from European family SMEs. Journal of World Business, 53(2), 237-247.

Majocchi, A. \& Strange, R. (2012). International diversification: the impact of ownership structure, the market for corporate control and board independence. Management International Review, 52(6), 879-900.

Manolova, T. S., Brush, C. G., Edelman, L. F., \& Greene, P. G. (2002). Internationalization of small firms: personal factors revisited. International Small Business Journal, 20(1), 9-31.

Marìn-Anglada, Q., Campa-Planas, F., \& Hernàndez-Lara, B. (2014). Uncertainty in the family business facing the process of internationalization: literature review and future research agenda. Intangible Capital, 10(4), 836-853.

Marlow, S. \& Patton, D. (2005). All credit to men? Entrepreneurship, finance, and gender. Entrepreneurship: Theory and Practice, 29(6), 717 - 735

Melin, L. (1992). Internationalization as a Strategy Process. Strategic Management Journal, 13, 99118.

Meyer, K. E. \& Estrin, S. (2001). Brownfiled Entry in Emerging Markets. Journal of International Business Studies, 32(3), 575-584.

Micelotta, E. R. \& Raynard, M. (2011). Concealing or revealing the family? Corporate brand identity strategies in family firms. Family Business Review, 24(3), 197-216.

Miles, M. B. \& Huberman, A. M. (1994). Qualitative data analysis, (2nd ed.). Thousand Oaks, CA: Sage Publications.

Miller, D., Steier, L. \& Le Breton-Miller, I. (2003). Lost in time: intergenerational succession, change, and failure in family business. Journal of Business Venturing, 18, 513-531.

Mitter, C., Duller, C., Feldbauer-Durstmuller, B., \& Kraus, S. (2014). Internationalization of family firms: the effect of ownership and governance. Review of Managerial Science, 8(1), 1-28.

Muñoz-Bullón, F. \& M. J. Sánchez-Bueno (2012). Do Family Ties Shape the Performance Consequences of Diversification? Evidence from the European Union. Journal of World Business, 47(3), 469-77. 
Nahapiet, J. \& Ghoshal, S. (1998). Social capital, intellectual capital, and the organizational advantage. Academy of Management Review, 23(2), 242-266.

Naldi, L., Nordqvist, M., Sjoberg, K., \& Wiklund, J. (2007). Entrepreneurial orientation, risk taking, and performance in family firms. Family Business Review, 20(1), 33-47

Ojala, A. (2009). Internationalization of knowledge-intensive SMEs: the role of network relationships in the entry to a psychically distant market. International Business Review, 18(1), 50-59.

Onetti, A., Zucchella, A., Jones, M. V., \& McDougall-Covin, P. P. (2012). Internationalization, Innovation and Entrepreneurship: Business Models for New Technology-Based Firms. Journal of Management and Governance, 16(3), 337-68.

Oviatt, B. M. \& McDougall, P. P. (2005). Defining international entrepreneurship and modelling the speed of internationalization. Entrepreneurship Theory and Practice, 29(5), 537-553.

Palmantier, R. W., Houston, M. B. \& Hulland, J. (2018). Review articles: purpose, process, and structure. Journal of the Academy of Marketing Science, 46, 1-5.

Paul, J., Parthasarathy, S., \& Gupta, P. (2017). Exporting challenges of SMEs: a review and future research agenda. Journal of World Business, 52(3), 327-342.

Penrose, E. T. (1959). The theory of the growth of the firm, New York, NY: Wiley.

Peteraf, M. A. (1993). The cornerstones of competitive advantage: a resource-based view. Strategic Management Journal, 14(3), 179-191.

Pongelli, C., Caroli, M. G., \& Cucculelli, M. (2016). Family business going abroad: the effect of family ownership on foreign market entry mode decisions. Small Business Economics, 47, 787801.

Pukall, T. J., \& Calabrò, A. (2014). The Internationalization of Family Firms: A Critical Review and Integrative Model. Family Business Review, 27(2), 103-125.

Ramon-Llorens, M. C., Garcia-Meca, E., \& Durendez, A. (2017). Influence of CEO characteristics in family firms internationalization. International Business Review, 26(4), 786-799.

Ramos-Rodríguez, A. -R. \& Ruíz- Navarro, J. (2004). Changes in the intellectual structure of strategic management research: a bibliometric study of the Strategic Management Journal. Strategic Management Journal, 25, 981-1004.

Rialp, A., Merigó, J. M., Cancino, C. A., \& Urbano, D. (2019). Twenty-five years (1992-2016) of the International Business Review: A bibliometric overview. International Business Review, 28(6), 101587.

Saeed A., Yousaf A., \& Alharbi J. (2017). Family and state ownership, internationalization and corporate board-gender diversity evidence from China and India. Cross Cultural and Strategic Management, 24(2), 251-270. 
Salvato, C. \& Melin, L. (2008). Creating value across generations in family-controlled businesses: the role of family social capital. Family Business Review, 21(3), 259-276.

Sanchez-Bueno, M. J. \& Usero, B. (2014). How may the nature of family firms explain the decisions concerning international diversification? Journal of Business Research, 67, 311-1320.

Sanders, W. G. \& Carpenter, M. A. (1998). Internationalization and firm governance: the roles of CEO compensation, top team composition, and board structure. Academy of Management Journal, 41(2), 158-178.

Schulze, W. S., Lubatkin, M. H., \& Dino, R. N., (2002). Altruism, agency, and the competitiveness of family firms. Managerial and Decision Economics, 23(4-5), 247-259.

Schulze, W. S., Lubatkin, M. H., \& Dino, R. N., (2003). Toward a theory of agency and altruism in family firms. Journal of Business Venturing, 18(4), 473-490.

Schulze, W. S., Lubatkin, M. H., Dino, R. N., \& Buchholtz, A. K. (2001). Agency relationships in family firms: theory and evidence. Organization Science, 12(2), 99-116.

Sciascia, S., Mazzola, P., Astrachan, J. H. \& Pieper, T. M. (2012). The role of family ownership in international entrepreneurship: exploring nonlinear effects. Small Business Economics, 38(1), $15-31$.

Sciascia, S., Mazzola, P., Astrachan, J. H., \& Pieper, T. M. (2013). Family involvement in the board of directors: effects on sales internationalization. Journal of Small Business Management, 51(1), 83-99.

Segaro, E. (2012). Internationalization of family SMEs: the impact of ownership, governance, and top management team. Journal of Management and Governance, 16, 147-169.

Segaro, E. L., Larimo, J., \& Jones, M. V. (2014). Internationalisation of family small and medium sized enterprises: the role of stewardship orientation, family commitment culture and top management team. International Business Review, 23, 381-395.

Sestu, M. C. \& Majocchi, A. (2018). Family firms and the choice between wholly owned subsidiaries and joint ventures: A Transaction Costs perspective. Entrepreneurship Theory and Practice, DOI: http://journals.sagepub.com/doi/10.1177/1042258718797925.

Sirmon, D. G., Arregle, J. -L., Hitt, M. A., \& Webb, J. W. (2008). The role of family influence in firms' strategic responses to threat of imitation. Entrepreneurship: Theory and Practice: 32(6), 979-988.

Sirmon, D. G. \& Hitt, M. A. (2003). Managing Resources: Linking Unique Resources, Management and Wealth Creation in Family Firms. Entrepreneurship: Theory and Practice, 27(4), 339-359. 
Surdu, I. \& Mellahi, K. (2016). Theoretical foundations of equity based foreign market entry decisions: a review of the literature and recommendations for future research. International Business Review, 25(5), 1169-1184.

Teece, D. J., Pisano, G., \& Shuen, A. (1997). Dynamic capabilities and strategic management. Strategic Management Journal, 18(7), 509-533.

Tsang, E. W. K. (2002). Learning from overseas venturing experience: the case of Chinese family businesses, Journal of Business Venturing, 17(1), 21-40.

Vahlne, J. -E. \& Johanson, J. (2017). From internationalization to evolution: the Uppsala model at 40 years. Journal of International Business Studies, 48, 1087-1102.

Van Eck, N. J. \& Waltman, L. (2010). Software Survey: VOSviewer, a Computer Program for Bibliometric Mapping. Scientometrics, 84(2), 523-538.

Verbeke, A., Yuan, W., \& Kano, L. (2019). A values-based analysis of bifurcation bias and its impact on family firm internationalization. Asia Pacific Journal of Management, DOI: https://doi.org/10.1007/s10490-018-9598-4

Vogel, R. \& Güttel, W. H. (2013). The dynamic capability view in strategic management: a bibliometric review. International Journal of Management Reviews, 15, 426-446.

Yli-Renko, H., Autio, E., \& Tontti, V. (2002). Social capital, knowledge, and the international growth of technology-based new firms. International Business Review, 11(3), 279-304.

Yin, R. K., (1994). Case study research: design and methods. Sage publications, Newbury Park, CA.

Zahra, S. A: (2019). Technological capabilities and international expansion: the moderating role of family and non-family firms' social capital. Asia Pacific Journal of Management, DOI: 10.1007/s10490-018-9607-7.

Zahra, S. A. (2003). International expansion of U.S. manufacturing family business: the effect of ownership and involvement. Journal of Business Venturing, 18, 495-512.

Zahra, S. A., Ireland, R. D., \& Hitt, M. A. (2000). International expansion by new venture firms: International diversity, mode of market entry, technological learning, and performance. Academy of Management Journal, 43(5),925-950

Zucchella, A., Palamara, G., \& Denicolai, S. (2007). The Drivers of the Early Internationalization of the Firm. Journal of World Business, 42(3), 268-280. 


\section{Appendix I}

The Appendices Ia and Ib show the relevance of the keywords along the years.

Appendix Ia. 373 keywords were identified by VOSviewer. We looked for the occurrences of a keyword with a minimum of 2 occurrences and 61 keywords meet the threshold. The top 30 used keywords are presented below:

\begin{tabular}{|l|r|l|l|r|}
\hline Keyword (1-15) & occurrences & & Keyword (16-30) & occurrences \\
\hline family firm & 91 & & entry mode & 4 \\
\hline internationalization & 59 & & family involvement & 4 \\
\hline sme & 13 & & family ownership & 4 \\
\hline innovation & 8 & & international diversification & 4 \\
\hline export & 6 & & strategy & 4 \\
\hline family sme & 6 & & bifurcation bias & 3 \\
\hline fdi & 6 & & board of directors & 3 \\
\hline international business & 6 & & family-owned firms & 3 \\
\hline ownership & 6 & & international expansion & 3 \\
\hline china & 5 & & ownership structure & 3 \\
\hline entrepreneurship & 5 & & pls-sem & 3 \\
\hline international entrepreneurship & 5 & & product diversification & 3 \\
\hline performance & 5 & & psychic distance & 3 \\
\hline socioemotional wealth & 5 & & social capital & 2 \\
\hline corporate governance & 4 & & agency conflicts & \\
\hline
\end{tabular}

Appendix Ib. The evolution of the keywords is provided below.

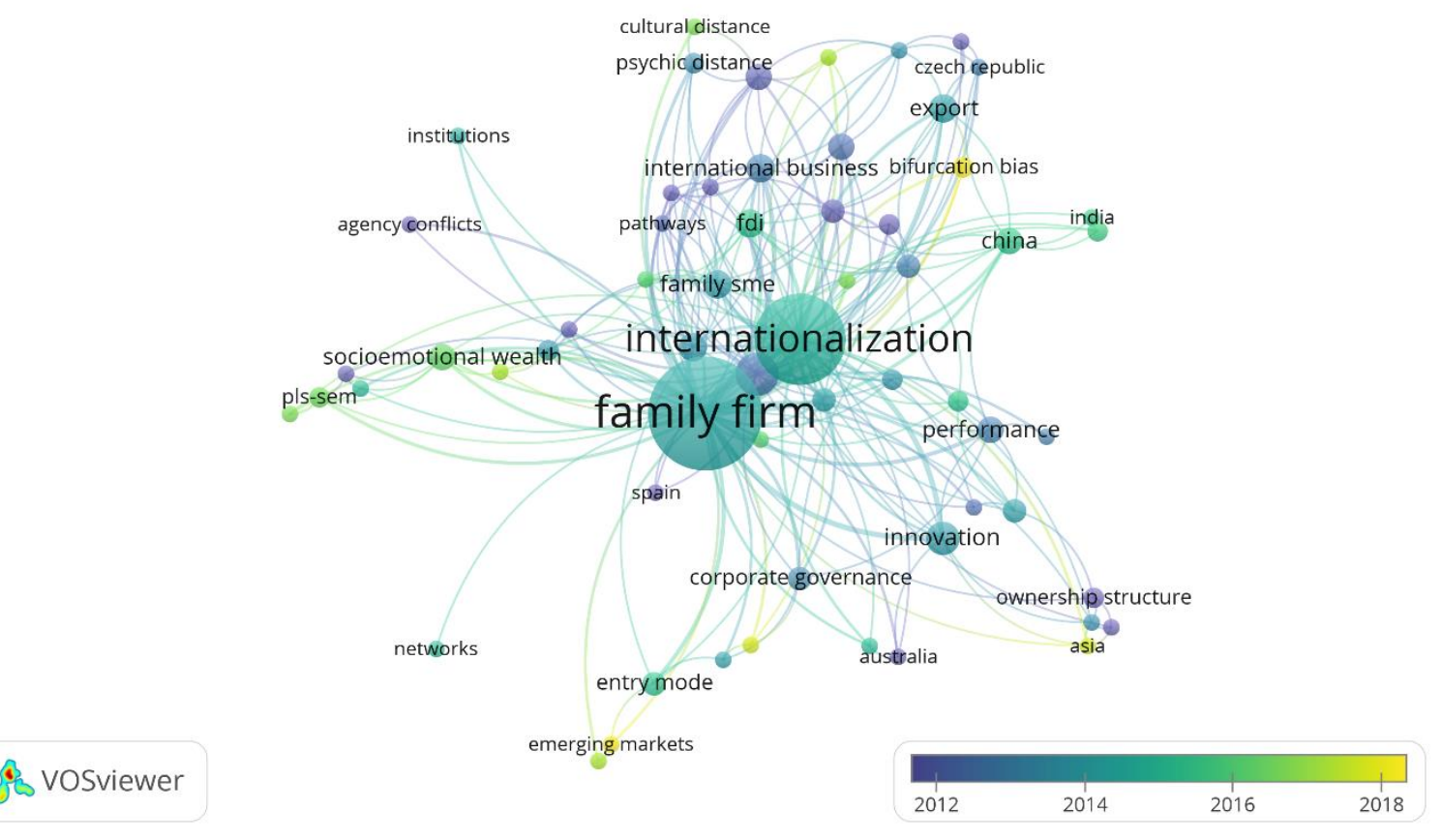


Appendix II. Links' strengths between themes and theoretical roots clusters

\begin{tabular}{|c|c|c|c|c|c|c|c|c|}
\hline & \multicolumn{7}{|c|}{ Theoretical roots } \\
\hline & & $\begin{array}{l}\text { RBV \& } \\
\text { UPP }\end{array}$ & $\begin{array}{l}\text { AGENCY T. \& DUN. EC. } \\
\text { PAR. }\end{array}$ & $\begin{array}{l}\text { BAM \& B.- } \\
\text { G. }\end{array}$ & $\begin{array}{l}\text { SOC. CAP. \& REV. UPP. \& REV. } \\
\text { INT. ENT. }\end{array}$ & $\begin{array}{l}\text { STEWARD. \& INT. } \\
\text { ENT. }\end{array}$ & $\begin{array}{l}\text { FF } \\
\text { BEH. }\end{array}$ & $\begin{array}{l}\text { EMERG. } \\
\text { MKT }\end{array}$ \\
\hline \multirow{4}{*}{$\begin{array}{l}\text { Themat } \\
\text { ic } \\
\text { clusters }\end{array}$} & $\begin{array}{l}\text { OWNERS } \\
\text { HIP }\end{array}$ & 0,47 & 0,11 & 0,04 & 0,15 & 0,08 & 0,13 & 0,03 \\
\hline & NETW. & 0,11 & 0,00 & 0,14 & 0,53 & 0,07 & 0,13 & 0,01 \\
\hline & IEO & 0,08 & 0,02 & 0,13 & 0,10 & 0,32 & 0,35 & 0,00 \\
\hline & $\begin{array}{l}\text { RES. } \\
\text { CONT. }\end{array}$ & 0,15 & 0,09 & 0,12 & 0,21 & 0,12 & 0,27 & 0,03 \\
\hline
\end{tabular}

